\author{
OAK RIDGE \\ NATIONAL LABORATORY \\ MANAGED BY UT-BATTELLE \\ FOR THE DEPARTMENT OF ENERGY
}

\section{Thermodynamic Modeling of Savannah River Evaporators}

\author{
C. F. Weber
}



ORNL/TM-2001/102

Computational Physics and Engineering Division (10)

\title{
Thermodynamic Modeling of Savannah River Evaporators
}

\author{
C. F. Weber
}

Date Published: August 2001

Prepared by the

OAK RIDGE NATIONAL LABORATORY

P.O. BOX 2008

Oak Ridge, Tennessee 37831-6370

managed by

UT-BATTELLE, LLC

for the

U.S. DEPARTMENT OF ENERGY

under contract DE-AC05-00OR22725 



\section{CONTENTS}

Page

LIST OF FIGURES $\ldots \ldots \ldots \ldots \ldots \ldots \ldots \ldots \ldots \ldots \ldots \ldots \ldots \ldots \ldots$

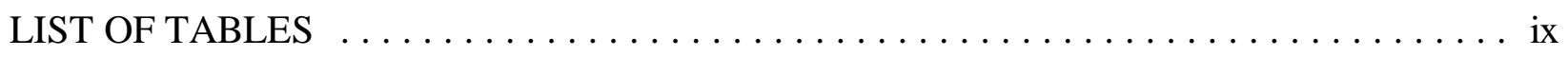

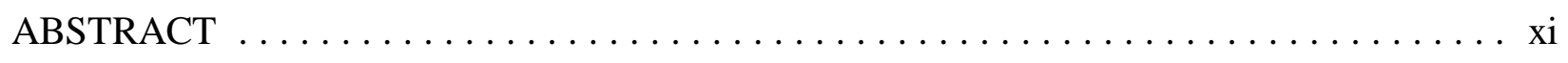

1. INTRODUCTION $\ldots \ldots \ldots \ldots \ldots \ldots \ldots \ldots \ldots \ldots \ldots \ldots \ldots \ldots \ldots$

2. DESCRIPTION OF CALCULATIONAL MODEL $\ldots \ldots \ldots \ldots \ldots \ldots \ldots \ldots \ldots \ldots$

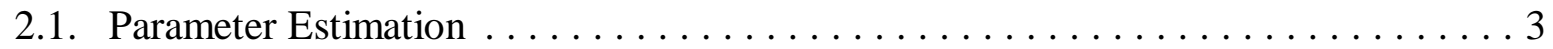

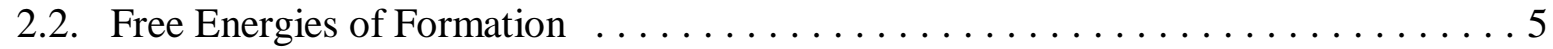

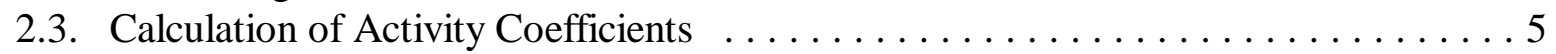

3. PARAMETER ESTIMATION AND MODEL CALCULATION . . . . . . . . . . 9

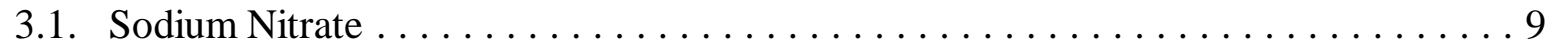

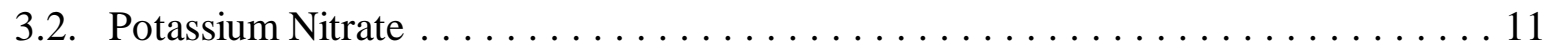

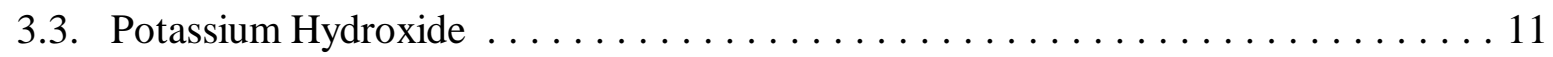

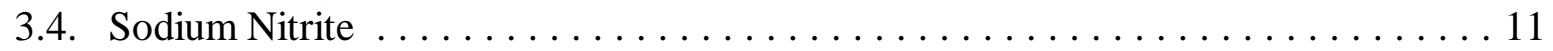

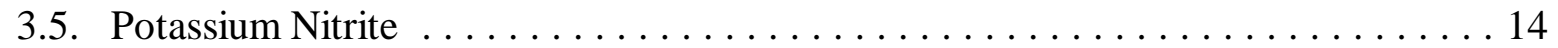

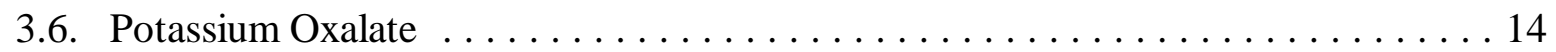

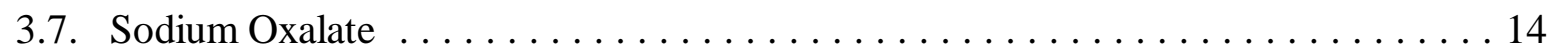

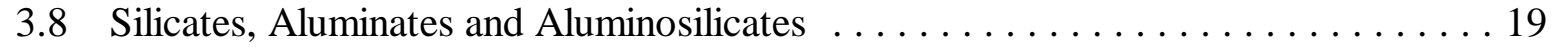

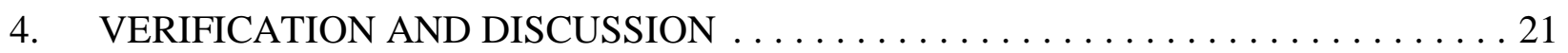

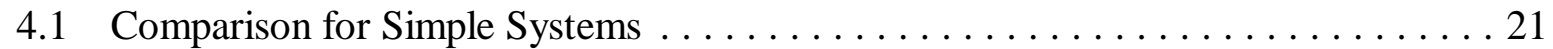

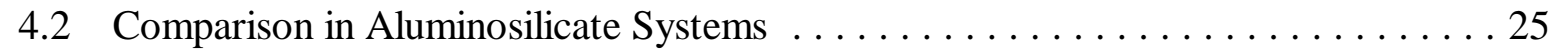

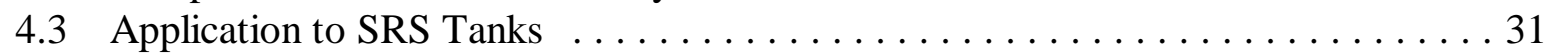

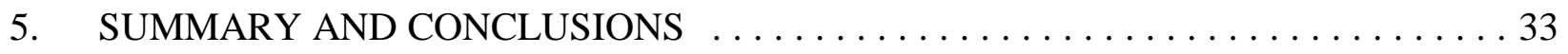

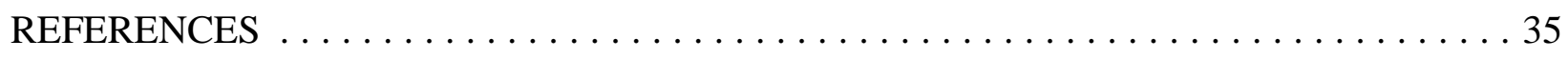

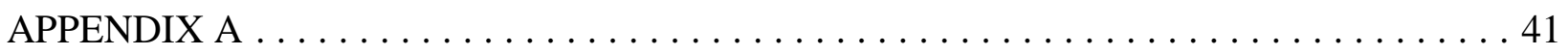




\section{LIST OF FIGURES}

Figure

Page

1. Osmotic coefficients in $\mathrm{NaNO}_{3}$ solutions at the freezing point.

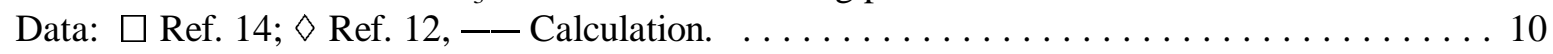

2. Osmotic coefficient in $\mathrm{NaNO}_{3}$ solutions at $25^{\circ} \mathrm{C}$.

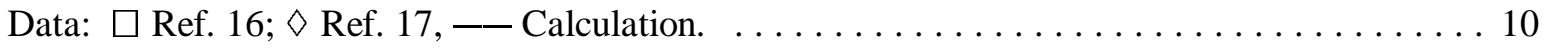

3. Osmotic coefficient in $\mathrm{NaNO}_{3}$ solutions.

Data from ref. 16: $\square 50^{\circ} \mathrm{C}, \diamond 75^{\circ} \mathrm{C}$. Calculations: $-50^{\circ} \mathrm{C},---75^{\circ} \mathrm{C} \ldots \ldots \ldots \ldots$

4. Osmotic coefficient in $\mathrm{NaNO}_{3}$ solutions at $100^{\circ} \mathrm{C}$.

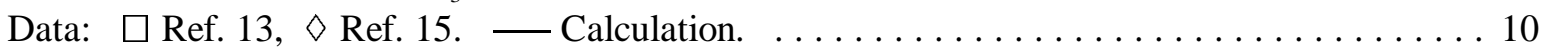

5. Osmotic coefficient in $\mathrm{KNO}_{3}$ solutions at the freezing point.

Data: $\square$ Ref. 12, $\diamond$ Ref. 14, $\Delta$ Ref. 16. —Calculation. ................... 12

6. Osmotic coefficient in $\mathrm{KNO}_{3}$ solutions at $25^{\circ} \mathrm{C}$.

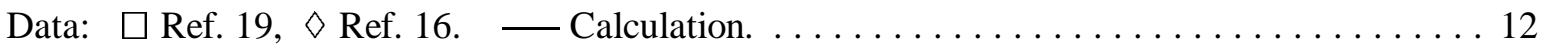

7. Osmotic coefficient in $\mathrm{KNO}_{3}$ solutions.

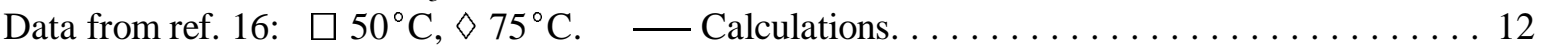

8. Osmotic coefficient in $\mathrm{KNO}_{3}$ solutions at $100^{\circ} \mathrm{C}$.

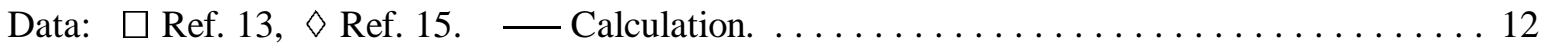

9. Activity coefficients of $\mathrm{KOH}$ solutions.

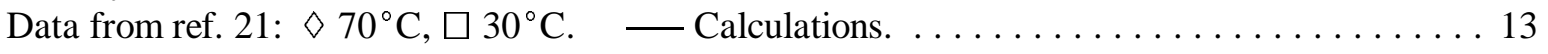

10. Osmotic coefficients of $\mathrm{KOH}$ solutions at $100^{\circ} \mathrm{C}$.

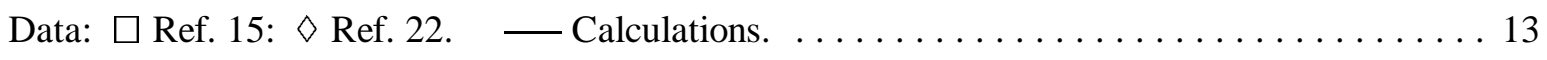

11. Osmotic coefficients of $\mathrm{NaNO}_{2}$ solutions at $25^{\circ} \mathrm{C}$.

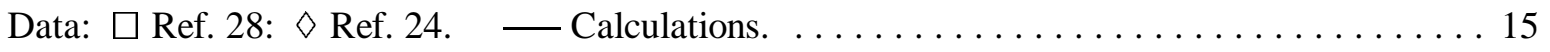

12. Osmotic coefficients in $\mathrm{NaNO}_{2}$ solutions at $50^{\circ} \mathrm{C}$.

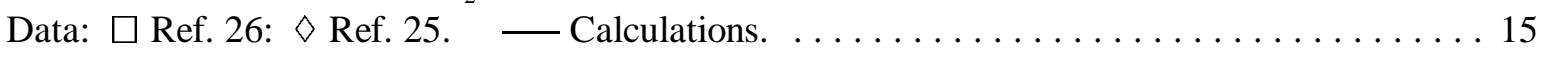

13. Osmotic coefficients in $\mathrm{NaNO}_{2}$ solutions at $100^{\circ} \mathrm{C}$.

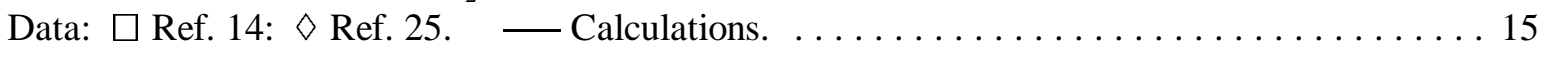

14. Enthalpies of dilution in $\mathrm{NaNO}_{2}$ solutions at $25^{\circ} \mathrm{C}$. Final concentrations were exactly

half the initial values. - Data from ref. 27. $\diamond$ Calculations. $\ldots \ldots \ldots \ldots \ldots \ldots \ldots$ 


\section{LIST OF FIGURES (continued)}

$\underline{\text { Figure }}$

Page

15. Osmotic coefficients of $\mathrm{KNO}_{2}$ solutions at $25^{\circ} \mathrm{C}$.

$\diamond$ Data from ref. 24.

Calculations.

16. Osmotic coefficients of $\mathrm{KNO}_{2}$ solutions at the freezing point.

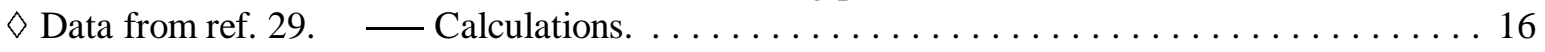

17. Osmotic coefficients of $\mathrm{KNO}_{2}$ solutions at $100^{\circ} \mathrm{C}$.

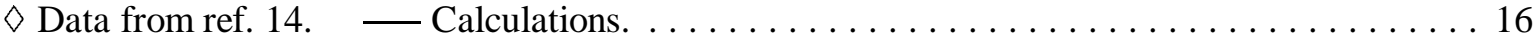

18. Osmotic coefficients for $\mathrm{K}_{2} \mathrm{C}_{2} \mathrm{O}_{4}$ solutions at the freezing point.

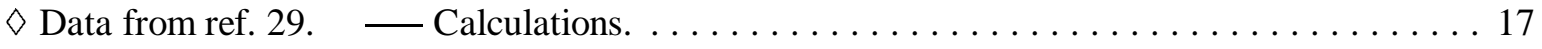

19. Osmotic coefficients for $\mathrm{K}_{2} \mathrm{C}_{2} \mathrm{O}_{4}$ solutions at $100^{\circ} \mathrm{C}$.

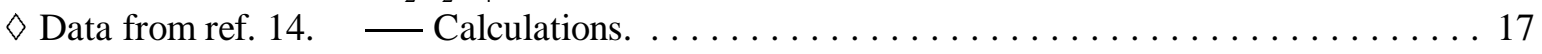

20. Dilution enthalpy for $\mathrm{K}_{2} \mathrm{C}_{2} \mathrm{O}_{4}$ solutions at $25^{\circ} \mathrm{C}$. Final concentration is half the initial

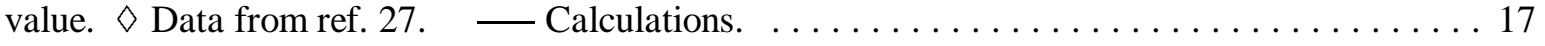

21. Solubility of $\mathrm{K}_{2} \mathrm{C}_{2} \mathrm{O}_{4}$ in water (solid phase is the monohydrate).

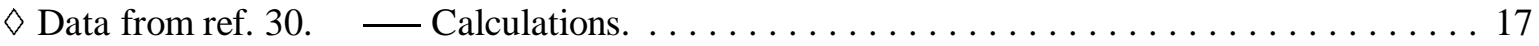

22. Solubility of $\mathrm{Na}_{2} \mathrm{C}_{2} \mathrm{O}_{4}$ in $\mathrm{NaOH}$ solutions at $0^{\circ} \mathrm{C}$.

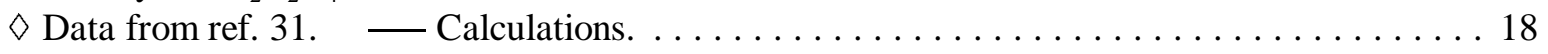

23. Solubility of $\mathrm{Na}_{2} \mathrm{C}_{2} \mathrm{O}_{4}$ in $\mathrm{NaOH}$ solutions at $30^{\circ} \mathrm{C}$.

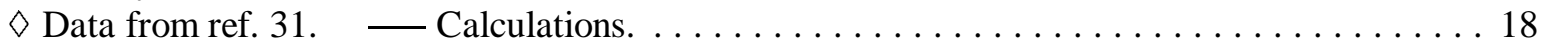

24. Solubility of $\mathrm{Na}_{2} \mathrm{C}_{2} \mathrm{O}_{4}$ in $\mathrm{NaOH}$ solutions at $50^{\circ} \mathrm{C}$.

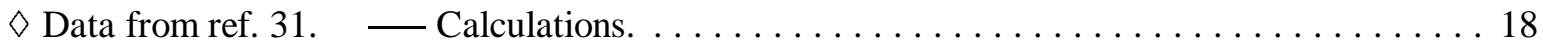

25. Solubility of $\mathrm{Na}_{2} \mathrm{C}_{2} \mathrm{O}_{4}$ in water.

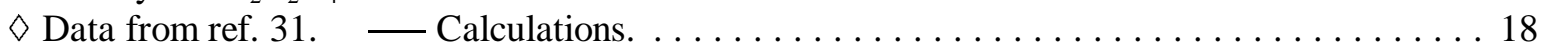

26. $\mathrm{SiO}_{2}$ solubility in dilute caustic solutions.

- Data from ref. 41. Code calculations: - SOLGASMIX, --- GWB. . . . . . . . . . . . 22

27. Gibbsite solubility in caustic solutions at $40^{\circ} \mathrm{C}$.

$\square$ Data from ref. 39 . Calculations: - SOLGASMIX, --- GWB. ............. 23

28. Gibbsite solubility in caustic solutions at $70^{\circ} \mathrm{C}$. $\square$ Data from ref. 39 .

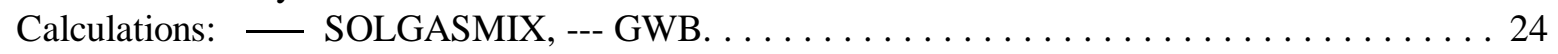




\section{LIST OF FIGURES (continued)}

$\underline{\text { Figure }}$

$\underline{\text { Page }}$

29. Gibbsite solubility in caustic solutions at $100^{\circ} \mathrm{C}$.

$\square$ Data from ref. 39. Calculations: - - SOLGASMIX, --- GWB.

30. Precipitation in SRS simulated solutions at $25^{\circ} \mathrm{C}$ (seeded with gibbsite).

Data from ref. 45. Solid horizontal lines are SOLGASMIX predictors.

31. $\quad$ SRS average simulated at $55^{\circ} \mathrm{C} . \diamond \diamond$ Data from ref. 46.

Calculations: — SOLGASMIX, ‥ GWB (sodalite), --- GWB (zeolite A),

-. - . GWB (mixed zeolite), $-. \cdot-. \cdot$ GWB (amorphous aluminosilicate). . . . . . . . . . . 27

32. SRS average simulated at $80^{\circ} \mathrm{C} . \quad \square$ Data from ref. 46.

Calculations: — SOLGASMIX, … GWB (sodalite), --- GWB (zeolite A),

- • - GWB (mixed zeolite), $-. \cdot-\cdot$ GWB (amorphous aluminosilicate). . . . . . . . . . . . 27

33. Precipitation in SRS High- $\mathrm{NO}_{3}$ simulant.

$\square \diamond$ Data from ref. 32. - SOLGASMIX prediction. $\ldots \ldots \ldots \ldots \ldots \ldots \ldots \ldots$

34. Cancrinite solubility in nitrate-nitrite-hydroxide solution at $80^{\circ} \mathrm{C}$.

Data from ref. 44: $\downarrow$ Al, $\square$ Si. SOLGASMIX Calculations: $-\mathrm{Al},---\mathrm{Si} . \ldots \ldots \ldots$

35. Cancrinite solubility in nitrate-nitrite-hydroxide solution at $120^{\circ} \mathrm{C}$.

Data from ref. 44: Al, $\square$ Si. SOLGASMIX Calculations: - Al, --- Si. . . . . . . . . 30

36. Solubility diagram for SRS Tank 43. $\square$ Dip samples $(12 / 23 / 00,10 / 18 / 00,7 / 30 / 00,5 / 6 / 00)$.

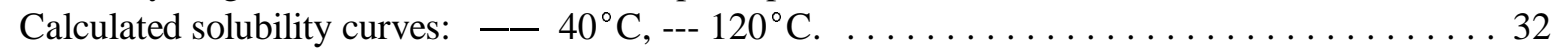

37. Solubility diagram for SRS Tank 32. $\square$ Dip samples $(2 / 15 / 01,12 / 5 / 00)$.

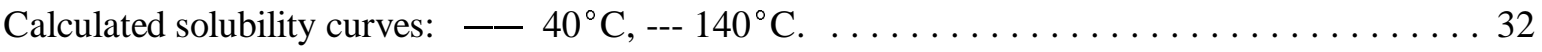




\section{LIST OF TABLES}

$\underline{\text { Table }} \quad \underline{\text { Page }}$

1. Components in aluminosilicate formation experiments $\ldots \ldots \ldots \ldots \ldots \ldots \ldots \ldots \ldots$

A.1. Coefficients for Gibbs Energy of Formation $\ldots \ldots \ldots \ldots \ldots \ldots \ldots \ldots \ldots \ldots \ldots$

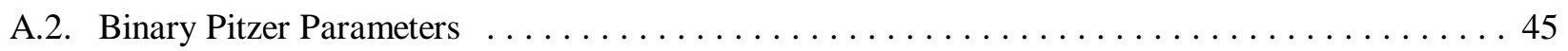

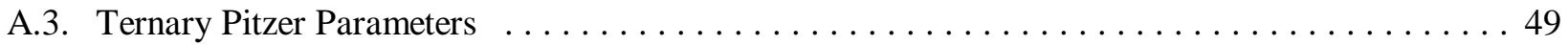




\begin{abstract}
A thermodynamic model based on the code SOLGASMIX is developed to calculate phase equilibrium in evaporators and related tank wastes at the Savannah River Site (SRS). This model uses the Pitzer method to calculate activity coefficients, and many of the required Pitzer parameters have been determined in the course of this work. Principal chemical species in standard SRS simulant solutions are included, and the temperature range for most parameters has been extended above $100^{\circ} \mathrm{C}$. The SOLGASMIX model and calculations using the code Geochemists Workbench are compared to actual solubility data including silicate, aluminate, and aluminosilicate solutions. In addition, SOLGASMIX model calculations are also compared to transient solubility data involving SRS simulant solutions. These comparisons indicate that the SOLGASMIX predictions closely match reliable data over the range of temperature and solution composition expected in the SRS evaporator and related tanks. Predictions using the Geochemists Workbench may be unreliable, due primarily to the use of an inaccurate activity coefficient model.
\end{abstract}




\section{INTRODUCTION}

The $2 \mathrm{H}$ evaporator in the $\mathrm{H}$ canyon at the Savannah River Site (SRS) has been confronted with several problems related to unexpected solids formation during the last few years. The gravity drain line to receipt tank $38 \mathrm{H}$ became clogged with an aluminosilicate material, and corrections included closer monitoring of process conditions. Later, extensive deposits within the evaporator itself caused shutdown of the evaporator, which requuired cleaning with $1.5 \mathrm{M}$ nitric acid and depleted uranium. These deposits are also predominately aluminosilicate solids, although uranyl compounds and amorphous aluminum compounds are also present. Subsequent analyses of the evaporator process and waste composition indicated that solids formation was likely, and even expected. The real challenge now facing SRS and DOE is how to predict problems before they occur, and to make corrections that will permit uninterrupted, safe operation. However, if these problems cannot be entirely avoided, then tank farm operations would like to determine the best ways to minimize the deposits so the frequency of the acid cleaning can be reduced.

Central to planning and operation of the evaporator is an effective means of modeling the chemical processes that occur throughout the system (including feed and receipt tanks, and piping). This report describes a chemical equilibrium model based on the SOLGASMIX ${ }^{1,2}$ code, which can be used to predict phase equilibrium in each region. All important constituents of SRS simulant are included, and temperatures for most species are reliable to at least $100^{\circ} \mathrm{C}$, and beyond. The model parameters are validated by comparison of predictive chemical calculations with a wide variety of data, including solubility data using SRS simulant.

In addition, a few comparisons are made using the code Geochemists Workbench ${ }^{3}$ (GWB). Some of the GWB calculations appear adequate, while others are seriously in error. The difficulties are primarily associated with the B.dot method of calculating activity coefficients, which is not designed for the high ionic strengths usually encountered in SRS wastes. 


\section{DESCRIPTION OF CALCULATIONAL MODEL}

The vehicle used for building a quantitative model is an adaptation of the chemical equilibrium code SOLGASMIX, ${ }^{1-2}$ modified to perform aqueous electrolyte calculations. This code calculates phase equilibrium by minimizing total free energy:

$$
G=\sum_{i} n_{i} \bar{G}_{i}=\sum_{i} n_{i}\left(G_{i}^{0}+R T \ln a_{i}\right)
$$

where $n_{i}, \bar{G}_{i}, a_{i}$, are the mole inventory, partial molar Gibbs free energy, and activity, respectively, of species $i$, and the summation includes all components of the system (including water). The molar free energies of formation $G_{i}^{0}$ (equal to the standard chemical potentials $\mu_{i}^{0}$ ) must be obtained from literature or estimated from data. In practice, it is helpful to use the reduced form $\mu_{i}^{0} / R T$. The activities are evaluated using the practical system: $a_{i}=m_{i} \gamma_{i}$ for solutes.

In order to cover a range of temperatures, the free energy functions $\hat{\mu}_{i} \equiv \mu_{i}^{0} / R T$ are considered to be functions of temperature of the form:

$$
\hat{\mu}_{i}=\mathrm{A}+\mathrm{B}\left(T-T_{0}\right)+\mathrm{C}\left(\frac{1}{T_{0}}-\frac{1}{T}\right)+\mathrm{D} \ln \frac{T}{T_{0}}+\mathrm{E}\left(T^{2}-T_{0}^{2}\right) .
$$

From Eq. (2), it is seen that $\hat{\mu}_{i}\left(T_{0}\right)=\mathrm{A}$, where $T_{0}=298.15 \mathrm{~K}$ throughout.

\subsection{Parameter Estimation}

A special module has been developed to perform nonlinear optimization, for the purpose of fitting the various parameters to actual data. For each data set, the phase equilibrium in Eq. (1) is obtained by calling the SOLGASMIX routines. 
The optimization is simply a nonlinear least squares procedure ${ }^{4,5}$

$$
\min _{\mathbf{p}} E=\min _{\mathbf{p}} \mathbf{e}^{\mathrm{T}} \mathbf{V e}
$$

$$
\begin{aligned}
& E=\text { total sum of squared error } \\
& \mathbf{p}=\text { vector of parameters to be optimized, } \\
& \mathbf{e}=\mathbf{x}-\hat{\mathbf{x}}=\text { error vector } \\
& \hat{\mathbf{x}}=\hat{\mathbf{x}}=\left(\hat{x}_{1}, \ldots, \hat{x}_{n}\right)^{\mathrm{T}}=\text { vector of data points } \\
& \mathbf{x}=\left(x_{1}, \ldots, x_{n}\right)^{\mathrm{T}}=\text { vector of calculated quantities } \\
& \mathbf{V}=\text { data covariance matrix. }
\end{aligned}
$$

The elements of the vector $\hat{\mathbf{x}}$ may involve a variety of data: equilibrium solubilities (i.e., aqueous concentrations), osmotic or activity coefficients, enthalpies or heat capacities, etc. Or it may contain quantities derived from such data - logarithms, sums or products, averages, etc. After experimental conditions have been ascertained (i.e., temperature, pressure, total inventories of all components), phase equilibrium is determined. The quantity $x_{i}$ is then calculated as a prediction of the data $\hat{x}_{i}$. (Of course, it is possible that more than one data point is related to a single equilibrium calculation.)

If all data points are independent, then the covariance matrix is given by

$$
\mathrm{V}=\operatorname{diag}\left(\sigma_{1}^{2}, \sigma_{2}^{2}, \ldots, \sigma_{N}^{2}\right)
$$

where $\sigma_{i}$ is the standard deviation of measurement $i$. The total squared error can then be written as

$$
E=\sum_{i=1}^{N}\left(x_{i}-\hat{x}_{i}\right)^{2} / \sigma_{i}^{2}
$$


It is seen in Eq. (3b) that the error contribution of each data point is weighted by the inverse of $\sigma_{i}^{2}$. This is important both to count "good" data more strongly (i.e., data with a small variance), and to normalize the error contributions of different types of data.

The actual technique used to solve Eq. (3a) is patterned after a procedure in Fletcher ${ }^{6}$ Because of the nonlinearity, iteration is necessary, and the approach uses both the Gauss-Newton and BFGS quasi-Newton methods, together with a step-length calculation.

\subsection{Free Energies of Formation}

Values for $\mu_{i}^{0}$ for most aqueous species are obtained from the HSC database $\frac{7}{7}$ since it is well documented and up-to-date. Furthermore, it matches very well the CODATA $^{8}$ values for water throughout the temperature range $0-100^{\circ} \mathrm{C}$. The CODATA selections are favored, since they were obtained through some international consensus, and are particularly applicable to solutions containing uranium and other actinides. Values of $\mu_{i}^{0}$ for most solids were obtained by regression of data (usually solubility data). For most aqueous ions, the HSC data are fit to a nonlinear functional form of Eq. (2). Gibbs energies for most solid species are chosen so as to closely match solubility data. Values of the various coefficients used are given in Appendix A.

\subsection{Calculation of Activity Coefficients}

In order to evaluate activity coefficients, the ion-interaction approach developed by Pitzer ${ }^{9,10}$ is used. Usually termed semi-empirical, Pitzer developed a statistical-mechanical basis for the dependence of the second viral coefficient on ionic strength. He then simplified the approach and developed equations for activity and osmotic coefficients which had adjustable parameters; these are fit empirically to macroscopic data for individual salt solutions or mixtures. 
For a binary system (i.e., a single salt dissolved in water) there are three parameters $\beta^{(0)}, \beta^{(1)}$, and $\mathrm{C}$; each of these must be determined by regression of actual data. For mixed salt solutions, two additional parameters $\theta$ and $\psi$ are used to describe interactions between 3 ions (two cations plus anion or two anions plus cation). All of these parameters may be temperature dependent.

The equations developed by Pitzer are

$$
\begin{gathered}
\varphi-1=\frac{2}{\Sigma m_{i}}\left\{-\frac{A_{\varphi} I^{3 / 2}}{1+b \sqrt{I}}+\sum_{i} \sum_{j} m_{i} m_{j}\left(B_{i j}^{\varphi}+Z C_{i j}\right)+\sum_{i} \sum_{j} m_{i} m_{j}\left(\Phi_{i j}^{\varphi}+\sum_{k} m_{k} \psi_{k i j}\right)\right\} \\
\ln \gamma_{j}=z_{j}^{2} F(I)+\sum_{i} m_{i}\left(2 B_{i j}+Z C_{i j}\right)+\sum_{i \neq j} m_{i}\left(2 \Phi_{i j}+m_{2} \Psi_{2 i j}\right)+\left|z_{j}\right| \sum_{k} \sum_{i} m_{i} m_{k} C_{k i},
\end{gathered}
$$

where, $I=1 / 2 \sum m_{i} z_{i}^{2}$ is the ionic strength, and

$$
\begin{gathered}
Z=\sum_{i=2}^{6} m_{i}\left|z_{i}\right| \\
B_{i j}^{\varphi}=\beta_{i j}^{(0)}+\beta_{i j}^{(1)} \exp (-\alpha \sqrt{I}) \\
B_{i j}=\beta_{i j}^{(0)}+\beta_{i j}^{(1)} g(\alpha \sqrt{I}), \quad g(x)=\frac{2}{x^{2}}\left[1-(1+x) \mathrm{e}^{-x}\right], \\
\Phi_{i j}^{\varphi}=\Phi_{i j}+I \Phi_{i j}^{\prime}, \quad \Phi_{i j}=\theta_{i j}+{ }^{E} \theta_{i j}(I), \\
F(I)=-A_{\varphi}\left[\frac{\sqrt{I}}{1+b \sqrt{I}}+\frac{2}{b} \ln (1+b \sqrt{I})+\sum_{i} \sum_{j} m_{i} m_{j} B_{i j}^{\prime}+\sum_{i} \sum_{j \neq i} m_{i} m_{j} \Phi_{i j}^{\prime}\right]
\end{gathered}
$$


and the prime symbol (') denotes differentiation with respect to ionic strength.

If the two ions have the same charges (e.g., $\mathrm{F}^{-}$and $\mathrm{OH}^{-}$), then the ${ }^{E} \theta=0$ and $\Phi_{i j}$ is independent of ionic strength. However, for ions whose charges have the same sign, but different magnitude (e.g., $\mathrm{OH}^{-}$and $\mathrm{PO}_{4}^{3-}$ ), then ${ }^{E} \theta_{i j}$ must be considered.

The parameters $\beta_{i j}^{(0)}, \beta_{i j}^{(1)}, C_{i j}, \theta_{i j}$, and $\Psi_{i j k}$ must be determined empirically from data. One of the strengths of Pitzer's ion-interaction approach is that behavior of components in mixed solutions is largely determined by the binary parameters $\beta_{i j}^{(0)}, \beta_{i j}^{(1)}$, and $C_{i j}$, with the mixture coefficients $\theta_{i j}$ and $\psi_{i j k}$ of secondary importance and significant only at higher ionic strengths. However, Harvie and coworkers ${ }^{11}$ have noted the importance of these mixture quantities in accurately modeling phase equilibria (i.e., solubilities). Hence, initially $\theta_{i j}$ and $\psi_{i j k}$ are assumed zero, but will be given non-zero values if data (especially solubility data) require it. 


\section{PARAMETER ESTIMATION AND MODEL CALCULATION}

Parameter values for most species of interest have been collected, either from the literature, or through regression of data, and are listed in Appendix A. Pitzer parameters were obtained from the literature for well known electrolytes such as $\mathrm{NaOH}$ and $\mathrm{NaCl}$, but most were obtained from regression of data, often in conjunction with Gibbs energies. Parameters for systems $\mathrm{Na}-\mathrm{Al}-\mathrm{OH}$, $\mathrm{Na}-\mathrm{OH}-\mathrm{PO}_{4}, \mathrm{Na}-\mathrm{F}, \mathrm{Na}-\mathrm{CO}_{3}, \mathrm{Na}-\mathrm{SO}_{4}$ were all taken from published literature. Regressions of particular significance to the evaporator project, and not previously reported, are described below.

\subsection{Sodium Nitrate}

Probably the best data (at temperatures other than $25^{\circ} \mathrm{C}$ ) are the freezing point depression measurements of Scatchard ${ }^{12}$ and the isopiestic data of Voigt ${ }^{13}$ at $100.3^{\circ} \mathrm{C}$. Highly consistent with the former are the freezing point values in the CRC handbook, ${ }^{14}$ which extend the concentration range from 1.7 to $4.6 \mathrm{~m}$. At higher concentrations, vapor pressure lowering dat ${ }^{15}$ at $100^{\circ} \mathrm{C}$ are consistent with the data of Voigt, and so have been included, with somewhat higher uncertainty. Vapor pressure data of Shpigel and Mischenko ${ }^{16}$ are available at $1,25,50$, and $75^{\circ} \mathrm{C}$, but appear to be of fair or poor quality. At $25^{\circ} \mathrm{C}$, these data yield osmotic coefficients with considerable scatter, when compared to the smoother values of $\mathrm{Wu}$ and Hamer ${ }^{17}$ (see Fig. 1). This comparison was the primary means of estimating uncertainties in the Russian data, which was applied to other temperatures as well. Below $2 \mathrm{~mol} / \mathrm{kg}$, all vapor pressure data are erratic and were not used. At $1{ }^{\circ} \mathrm{C}$, they are highly inconsistent with the freezing point data, and hence were not used. The values at 50 and $75^{\circ} \mathrm{C}$ were included for $m>2$, although their high uncertainties imply that their calculational weights were fairly light. Model calculations of osmotic coefficients at various temperatures are compared with data in Figs. 1-4 and indicate good agreement within the uncertainty of the data. 


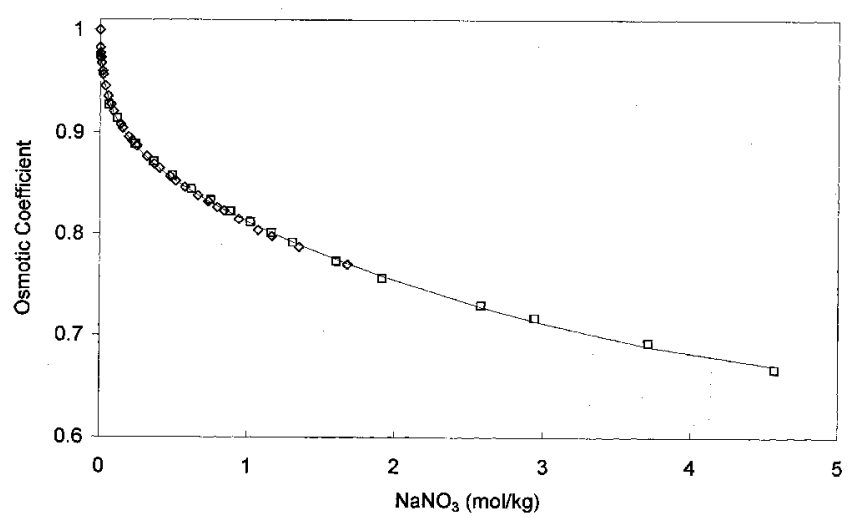

Fig. 1. Osmotic coefficients in $\mathrm{NaNO}_{3}$ solutions at the freezing point. Data: $\square$ Ref. 14; $\diamond$ Ref. 12, - Calculation.

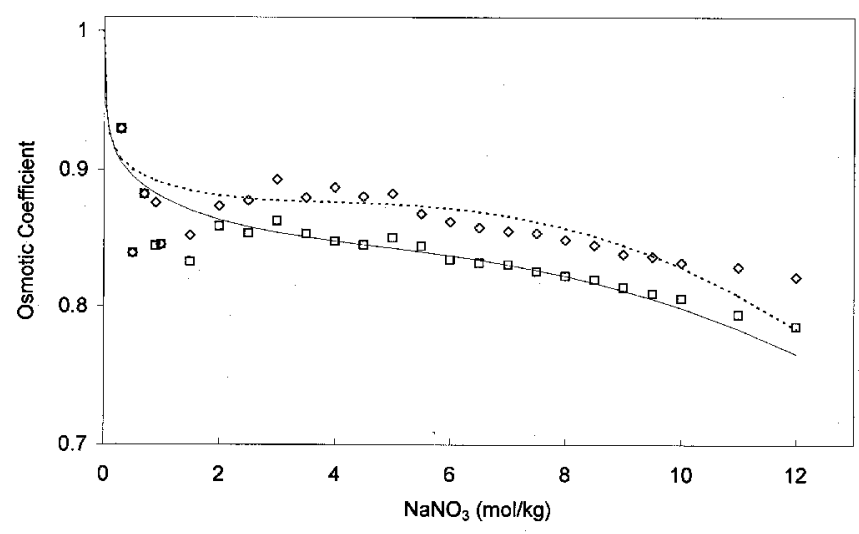

Fig. 3. Osmotic coefficient in $\mathrm{NaNO}_{3}$ solutions. Data from ref. 16: $\square 50^{\circ} \mathrm{C}, \diamond 75^{\circ} \mathrm{C}$. Calculations: $-50^{\circ} \mathrm{C},--75^{\circ} \mathrm{C}$.

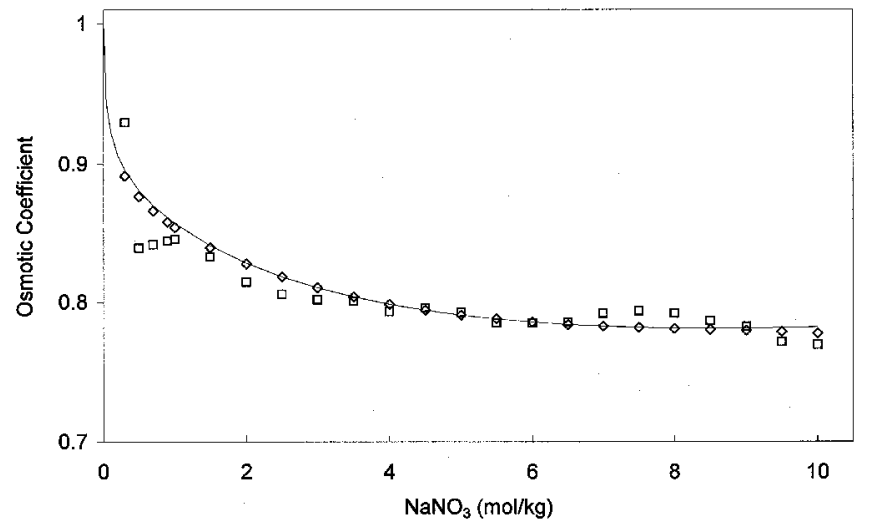

Fig. 2. Osmotic coefficient in $\mathrm{NaNO}_{3}$ solutions at $25^{\circ} \mathrm{C}$. Data: $\square$ Ref. 16; $\diamond$ Ref. 17, Calculation.

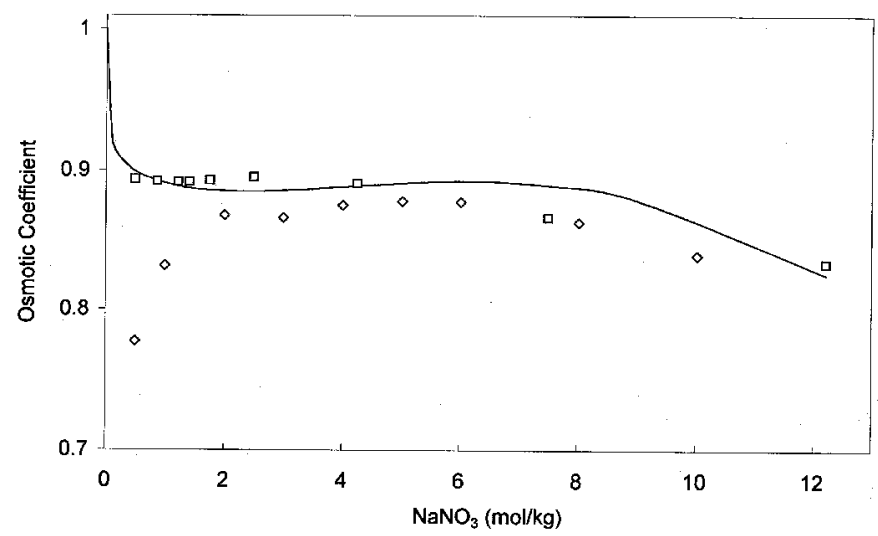

Fig. 4. Osmotic coefficient in $\mathrm{NaNO}_{3}$ solutions at $100^{\circ} \mathrm{C}$. Data: $\square$ Ref. 13, $\diamond$ Ref. 15. — Calculation. 


\subsection{Potassium Nitrate}

Available data are similar to that for $\mathrm{NaNO}_{3}$. Freezing point depression measurements of Scatchard ${ }^{12}$ and the CRC Handbook ${ }^{14}$ are in excellent agreement with each other. Isopiestic measurements ${ }^{18}$ at $100^{\circ} \mathrm{C}$ agree well with the earlier vapor pressure data. ${ }^{15}$ Again, the Russian vapor pressure data ${ }^{\sqrt{16}}$ at $1,25,50$, and $75^{\circ} \mathrm{C}$ are not of as high a quality but are useful nevertheless. Their results at $25^{\circ} \mathrm{C}$ are compared with smoothed values of Hamer and $\mathrm{W}^{19}$ to obtain uncertainty estimates, which are applied to values at 50 and $75^{\circ} \mathrm{C}$ as well. Again, the values at $1{ }^{\circ} \mathrm{C}$ are inconsistent with the freezing point data and judged to be of much poorer quality; they were therefore not used. Model calculations are compared with data in Figs. 5-8 and indicate good agreement. It is important to note that concentrations are fairly low at the lower temperatures, due to the solubility limit.

\subsection{Potassium Hydroxide}

Available data include e.m.f. measurement $s^{\sqrt{20,21}}$ from 0 to $70^{\circ} \mathrm{C}$, freezing point depression measurements, $\frac{14}{14}$ and vapor pressure lowering ${ }^{\sqrt{15}}$ at $100^{\circ} \mathrm{C}$. The freezing point data seem to be somewhat erratic, and therefore have considerably higher uncertainties than the low temperature e.m.f. data. The smoothed summary values of Hamer and $\mathrm{Wu}$ (19 are also available at $25^{\circ} \mathrm{C}$, and are reasonably consistent with e.m.f. results. Balej $j^{22}$ has stated an empirical equation using some room temperature data and Russian data above $150^{\circ} \mathrm{C}$. However, his values between 25 and $100^{\circ} \mathrm{C}$ are not consistent with the other data mentioned here and have not been included. Model calculations are compared to data in Figs. 9 and 10, and indicate excellent agreement through the temperature range $30-100^{\circ} \mathrm{C}$, and to quite high ionic strength. Comparisons at other temperatures are similar.

\subsection{Sodium Nitrite}

Data of Staples ${ }^{23}$ and Chekhunovi ${ }^{24}$ at $25^{\circ} \mathrm{C}$ are fairly consistent and were used to obtain base values for Pitzer parameters. Vapor pressure data at $100^{\circ} \mathrm{C}$ from the CRC Handbook ${ }^{[14}$ are not consistent with isopiestic data. ${ }^{25}$ However, the latter are more consistent with data at saturation ${ }^{26}$ and dilution enthalpies $\stackrel{27}{2}$ so were preferred in estimation of temperature coefficients. 


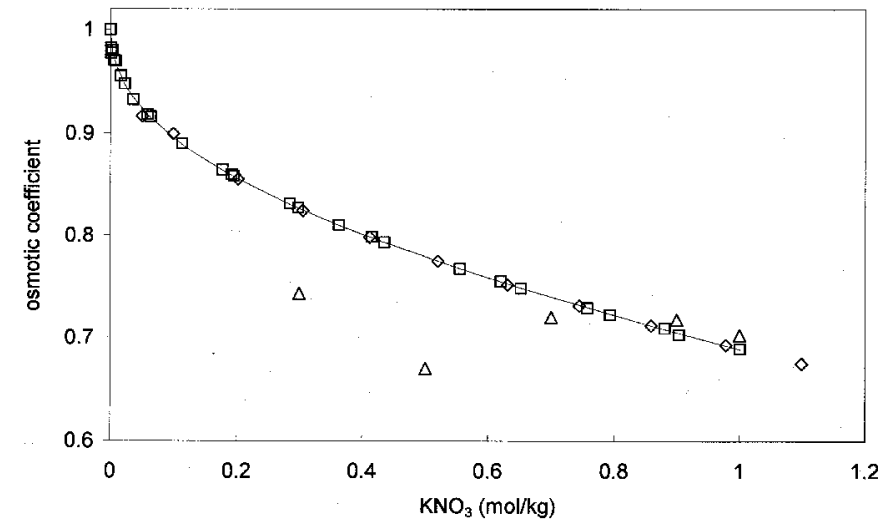

Fig. 5. Osmotic coefficient in $\mathrm{KNO}_{3}$ solutions at the freezing point. Data: $\square$ Ref. 12, $\diamond$ Ref. 14, $\Delta$ Ref. 16. Calculation.

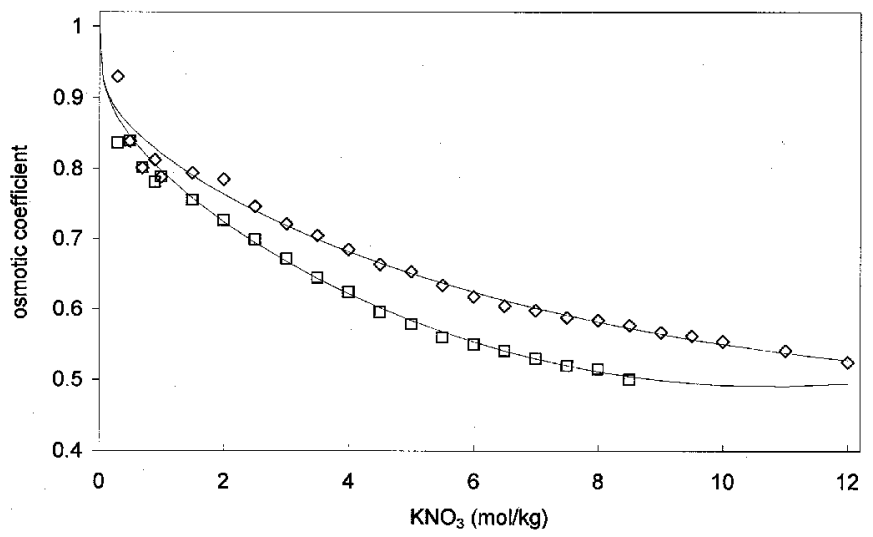

Fig. 7. Osmotic coefficient in $\mathrm{KNO}_{3}$ solutions. Data from ref. 16: $\square 50^{\circ} \mathrm{C}, \diamond 75^{\circ} \mathrm{C}$. — Calculations.

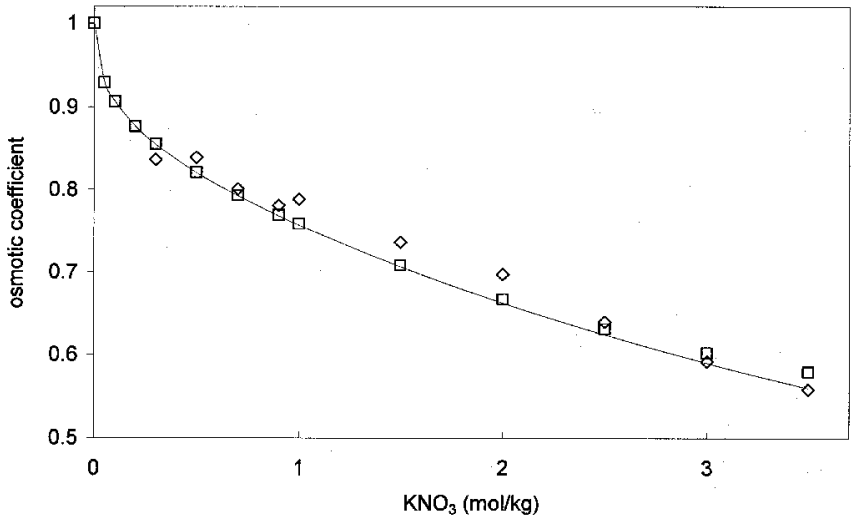

Fig. 6. Osmotic coefficient in $\mathrm{KNO}_{3}$ solutions at $25^{\circ} \mathrm{C}$. Data: $\square$ Ref. 19, $\diamond$ Ref. 16 . - Calculation.

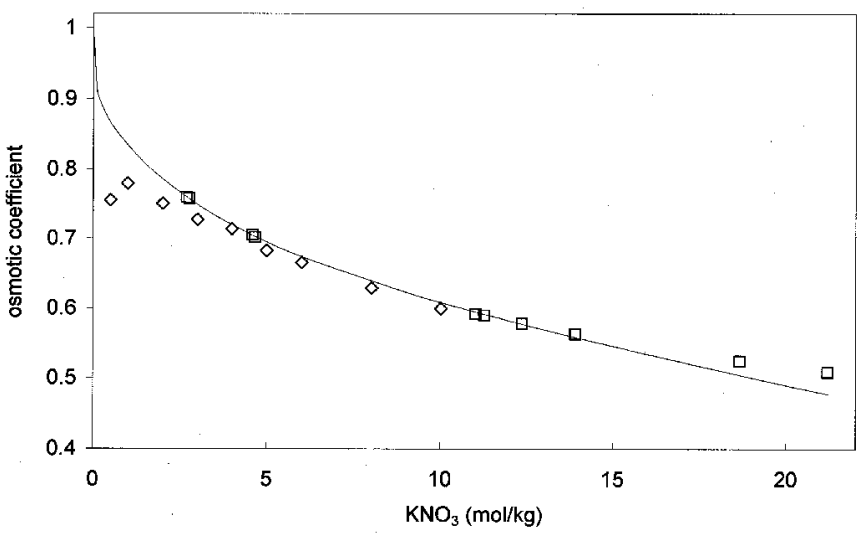

Fig. 8. Osmotic coefficient in $\mathrm{KNO}_{3}$ solutions at $100^{\circ} \mathrm{C}$. Data: $\square$ Ref. 13, $\diamond$ Ref. 15. Calculation. 


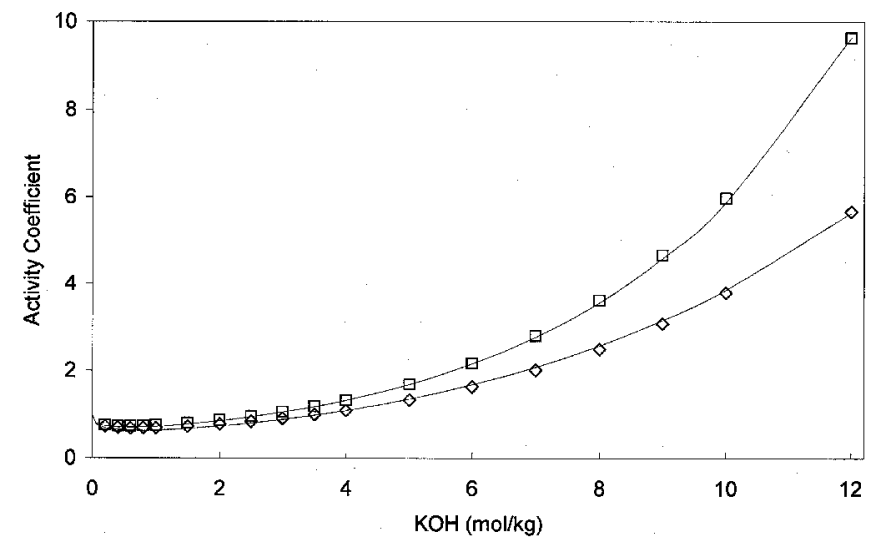

Fig. 9. Activity coefficients of $\mathrm{KOH}$ solutions. Data from ref. 21: $\diamond 70^{\circ} \mathrm{C}, \square 30^{\circ} \mathrm{C}$. Calculations.

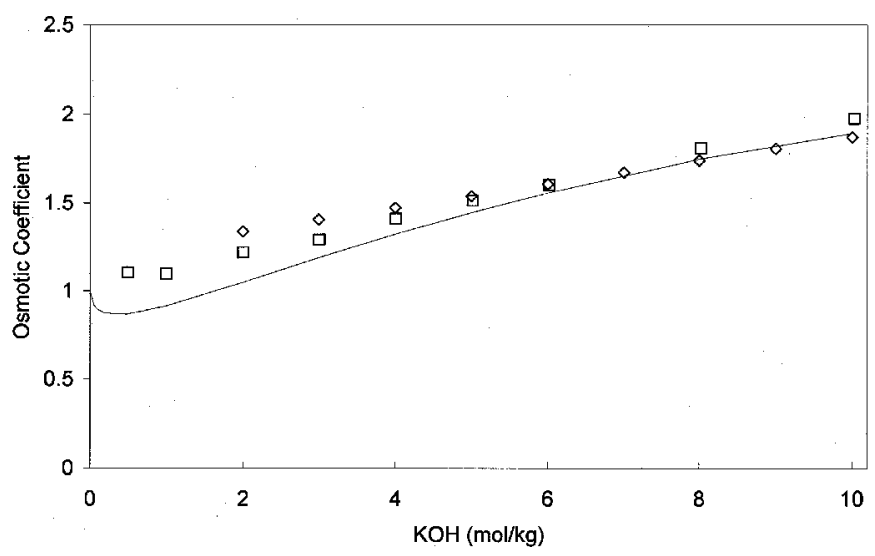

Fig. 10. Osmotic coefficients of $\mathrm{KOH}$ solutions at 100 C. Data: $\square$ Ref. 15: $\diamond$ Ref. 22. — Calculations. 
Data are compared with model calculations in Figs. 11-14. At $25^{\circ} \mathrm{C}$, the data from ref. 24 show a noticeable discontinuity between 5 and $6 \mathrm{~m}$. The calculation indicates a maximum in the osmotic coefficient near $10 \mathrm{~m}$, which seems more exaggerated than the data should allow. However, such a maximum is readily apparent in both data and calculations at higher temperatures (Figs. 12 and 13). The dilution enthalpy data of ref. 27 indicated a constant value for dilutions to half the initial concentration. This value $(576 \mathrm{~J} / \mathrm{mol})$ is indicated by the line in Fig. 14, and is matched by calculations within the error of the data.

\subsection{Potassium Nitrite}

Binary data for this salt are not extensive, but adequate. Values of Chekhunovi ${ }^{\sqrt{24}}$ at $25^{\circ} \mathrm{C}$ are used to generate base values. Temperature coefficients were obtained from freezing point dat $\mathrm{a}^{28}$ and vapor pressures at $100^{\circ} \mathrm{C} ! 14$ Calculations match data quite well at all three temperatures, as shown in Figs. 15-17.

\subsection{Potassium Oxalate}

Oddly enough, no activity data are available at $25^{\circ} \mathrm{C}$, although some are available at other temperatures. Freezing point depression, ${ }^{29}$ vapor pressure at $100^{\circ} \mathrm{C}, 14$ dilution enthalpy, $\frac{27}{}$ and solubility measurement $\mathrm{s}^{30}$ were used to estimate Pitzer parameters and Gibbs energy of formation for solid $\mathrm{K}_{2} \mathrm{C}_{2} \mathrm{O}_{4}$. Comparisons between data and model calculations are shown in Figs. 18-21. Agreement is quite good for osmotic coefficients at the freezing point and $100^{\circ} \mathrm{C}$, and for the dilution enthalpies at $25^{\circ} \mathrm{C}$. The solubilities are somewhat overpredicted at higher temperatures, likely due to the high ionic strengths involved.

\subsection{Sodium Oxalate}

Binary system data are more sparse than for $\mathrm{K}_{2} \mathrm{C}_{2} \mathrm{O}_{4}$ - only vapor pressure data at $100^{\circ} \mathrm{C}$ were available. ${ }^{14}$ Hence, we rely on solubility data even for binary parameters. Fortunately, considerable solubility data are available, in both $\mathrm{NaOH}$ and $\mathrm{NaNO}_{3}$ solutions, ${ }^{31-37}$ at many temperatures. Model calculations are compared with solubility data in Figs. 22-25, and show good agreement in neutral solutions and in $\mathrm{NaOH}$ solutions. Similar results hold also for solutions containing $\mathrm{NaNO}_{3}$, but are not shown. 


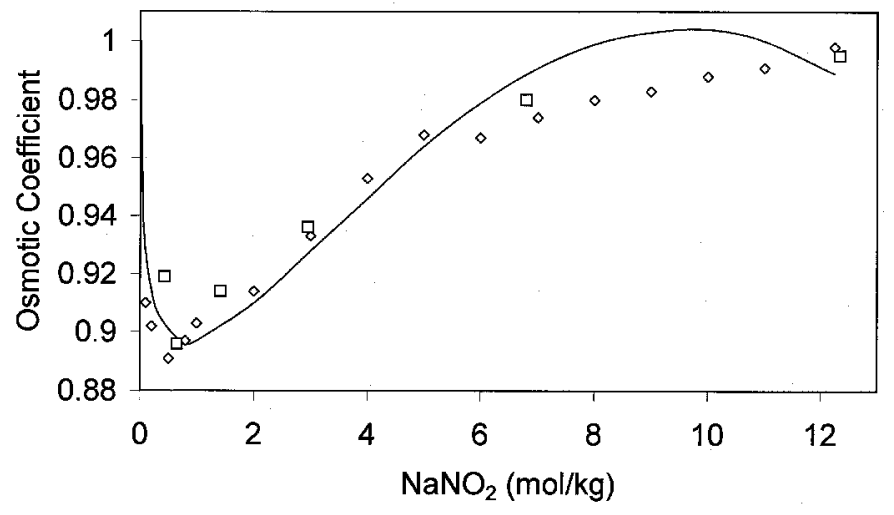

Fig. 11. Osmotic coefficients of $\mathrm{NaNO}_{2}$ solutions at $25^{\circ} \mathrm{C}$. Data: $\square$ Ref. 28: $\diamond$ Ref. 24. - Calculations.

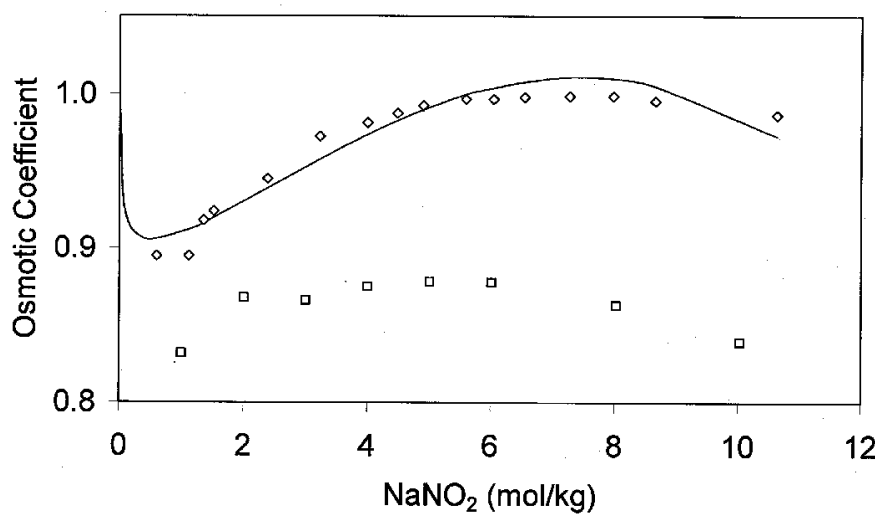

Fig. 13. Osmotic coefficients in $\mathrm{NaNO}_{2}$ solutions at $100^{\circ} \mathrm{C}$. Data: $\square$ Ref. 14:

$\diamond$ Ref. 25. Calculations.

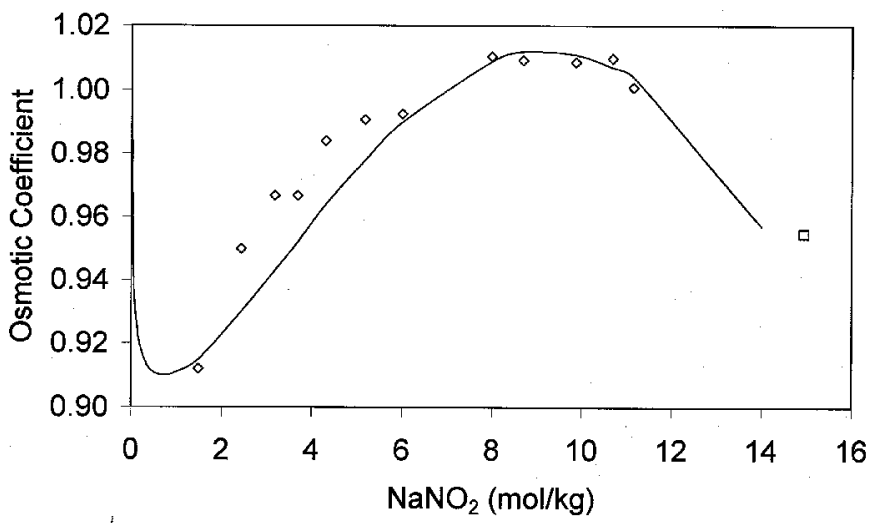

Fig. 12. Osmotic coefficients in $\mathrm{NaNO}_{2}$ solutions at $50^{\circ} \mathrm{C}$. Data: $\square$ Ref. 26: $\diamond$ Ref. 25. - Calculations.

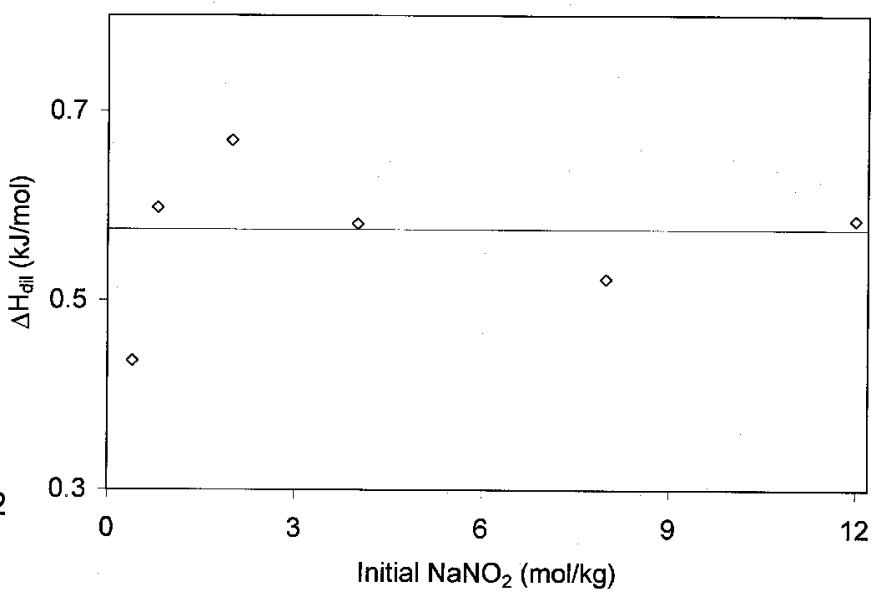

Fig. 14. Enthalpies of dilution in $\mathrm{NaNO}_{2}$ solutions at $25^{\circ} \mathrm{C}$. Final concentrations were exactly half the initial values. — Data from ref. $27 . \diamond$ Calculations. 


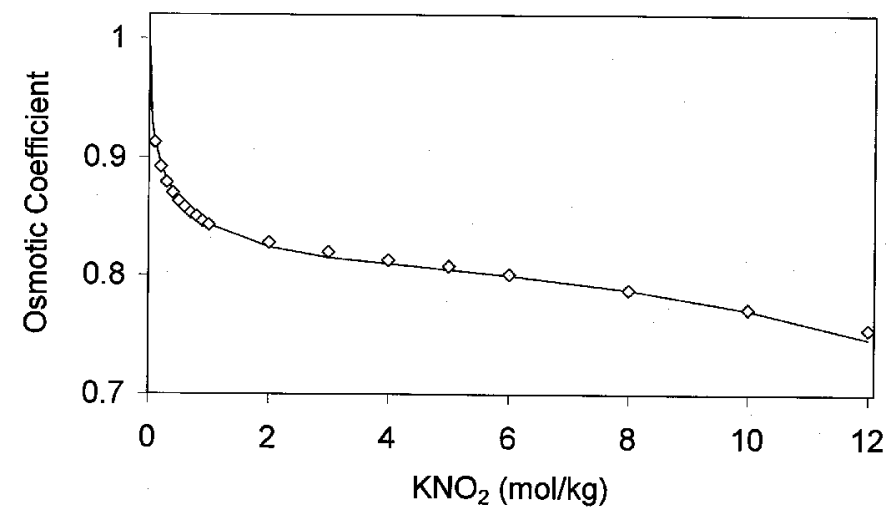

Fig. 15. Osmotic coefficients of $\mathrm{KNO}_{2}$ solutions at $25^{\circ} \mathrm{C}$. $\diamond$ Data from ref. 24 .

Calculations.

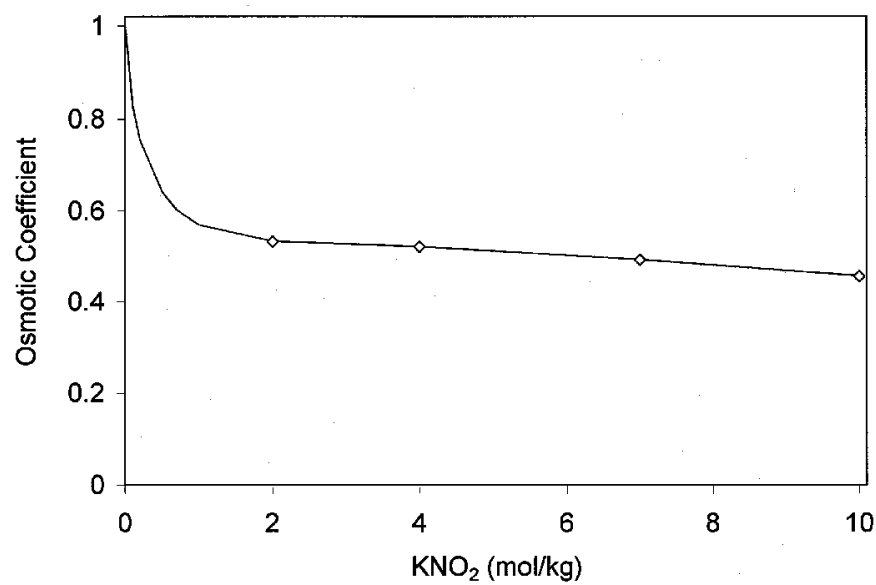

Fig. 16. Osmotic coefficients of $\mathrm{KNO}_{2}$ solutions at the freezing point. $\diamond$ Data from ref. 29 . Calculations.

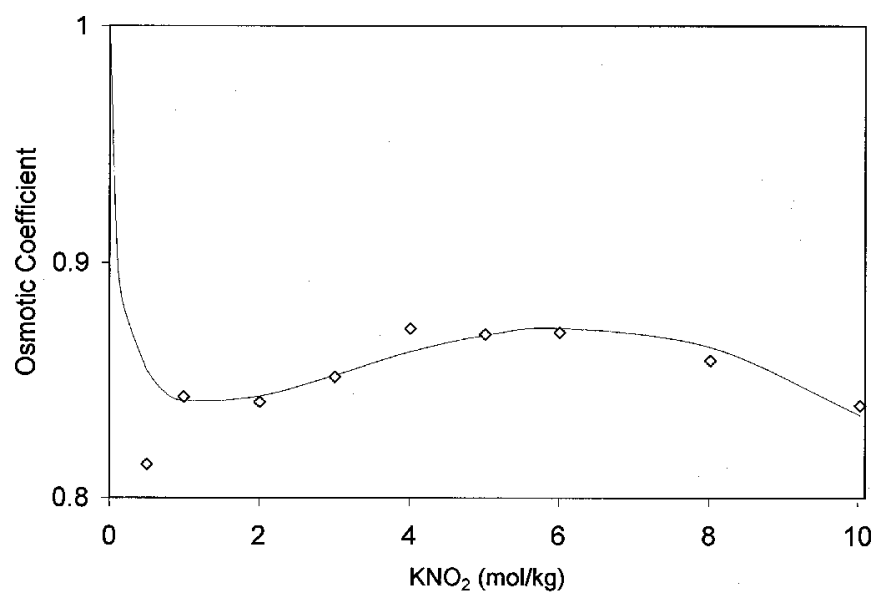

Fig. 17. Osmotic coefficients of $\mathrm{KNO}_{2}$ solutions at $100^{\circ} \mathrm{C}$. $\diamond$ Data from ref. 14 . Calculations. 


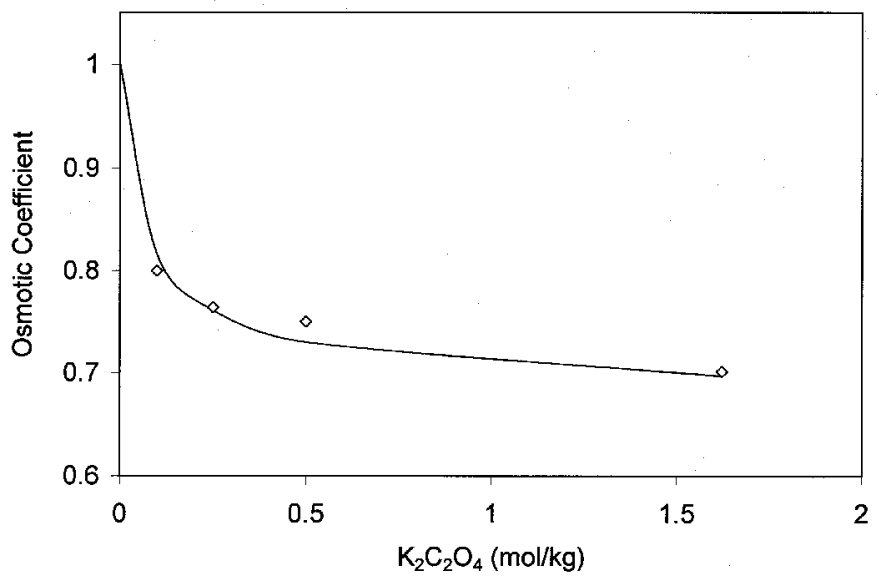

Fig. 18. Osmotic coefficients for $\mathrm{K}_{2} \mathrm{C}_{2} \mathrm{O}_{4}$ solutions at the freezing point. $\diamond$ Data from ref. 29. - Calculations.

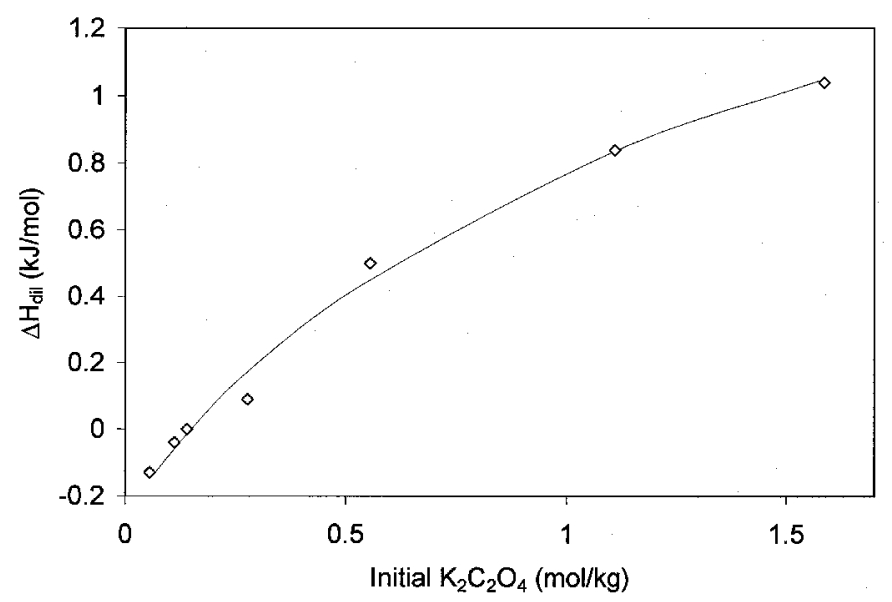

Fig. 20. Dilution enthalpy for $\mathrm{K}_{2} \mathrm{C}_{2} \mathrm{O}_{4}$ solutions at $25^{\circ} \mathrm{C}$. Final concentration is half the initial value. $\diamond$ Data from ref. 27. - Calculations.

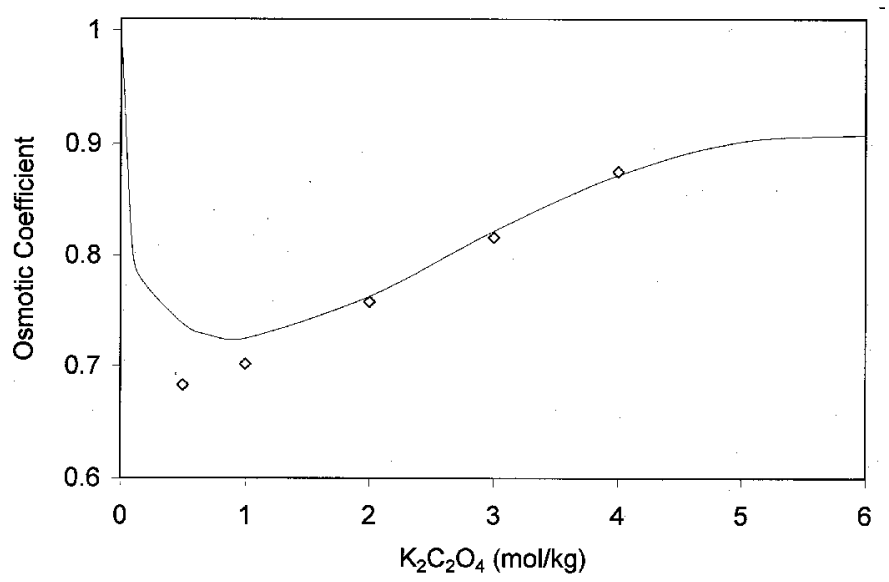

Fig. 19. Osmotic coefficients for $\mathrm{K}_{2} \mathrm{C}_{2} \mathrm{O}_{4}$ solutions at $100^{\circ} \mathrm{C}$. $\diamond$ Data from ref. 14 . - Calculations.

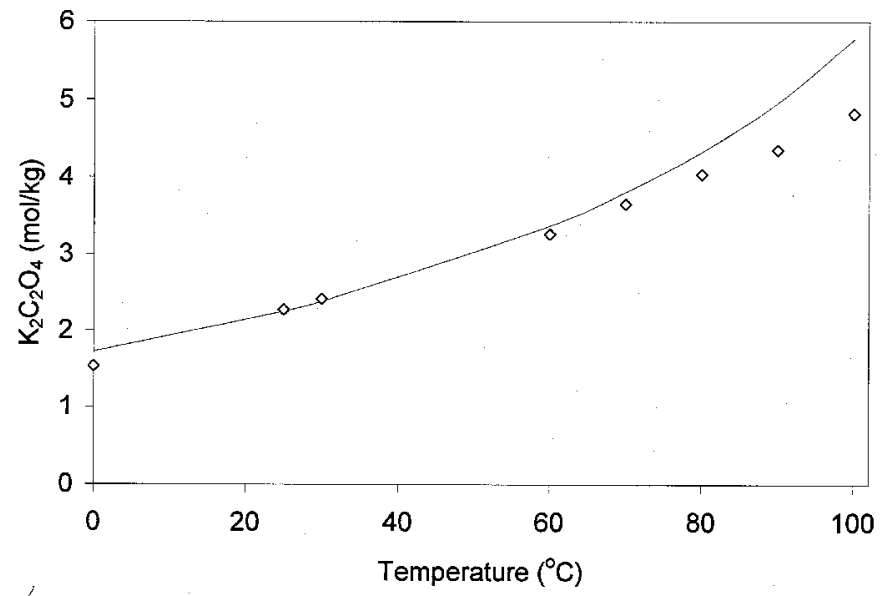

Fig. 21. Solubility of $\mathrm{K}_{2} \mathrm{C}_{2} \mathrm{O}_{4}$ in water (solid phase is the monohydrate). $\diamond$ Data from ref. 30 . Calculations. 


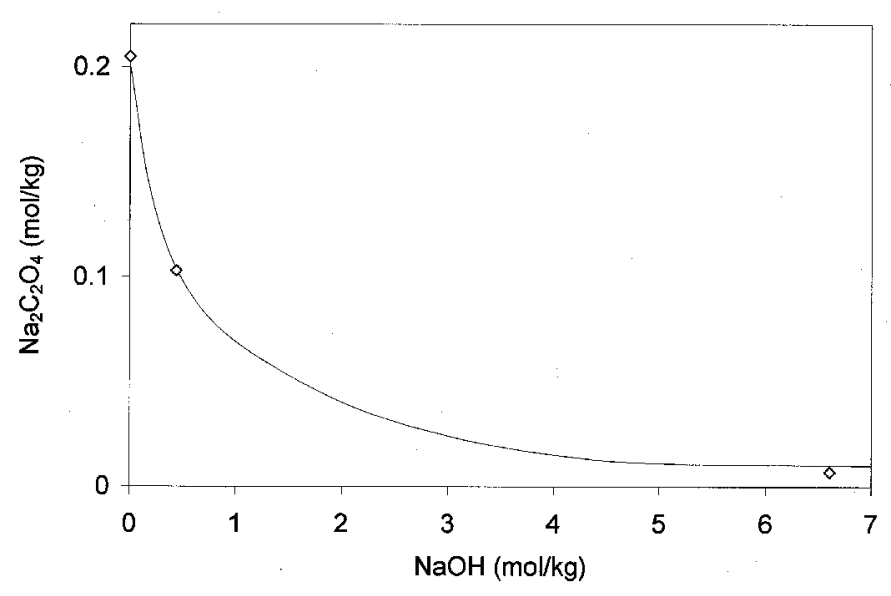

Fig. 22. Solubility of $\mathrm{Na}_{2} \mathrm{C}_{2} \mathrm{O}_{4}$ in $\mathrm{NaOH}$ solutions at $0^{\circ} \mathrm{C}$. $\diamond$ Data from ref. 31 . - Calculations.

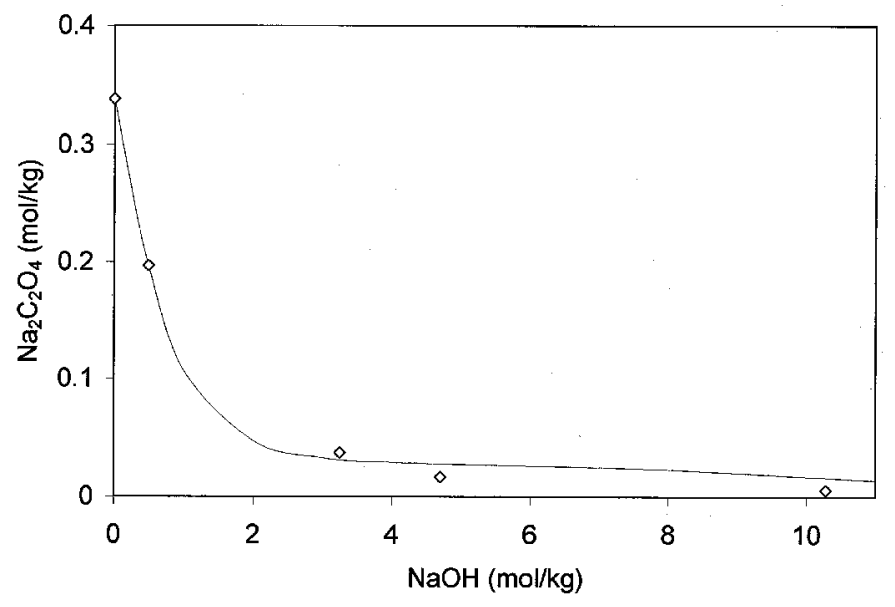

Fig. 24. Solubility of $\mathrm{Na}_{2} \mathrm{C}_{2} \mathrm{O}_{4}$ in $\mathrm{NaOH}$ solutions at $50^{\circ} \mathrm{C}$. $\diamond$ Data from ref. 31 . Calculations.

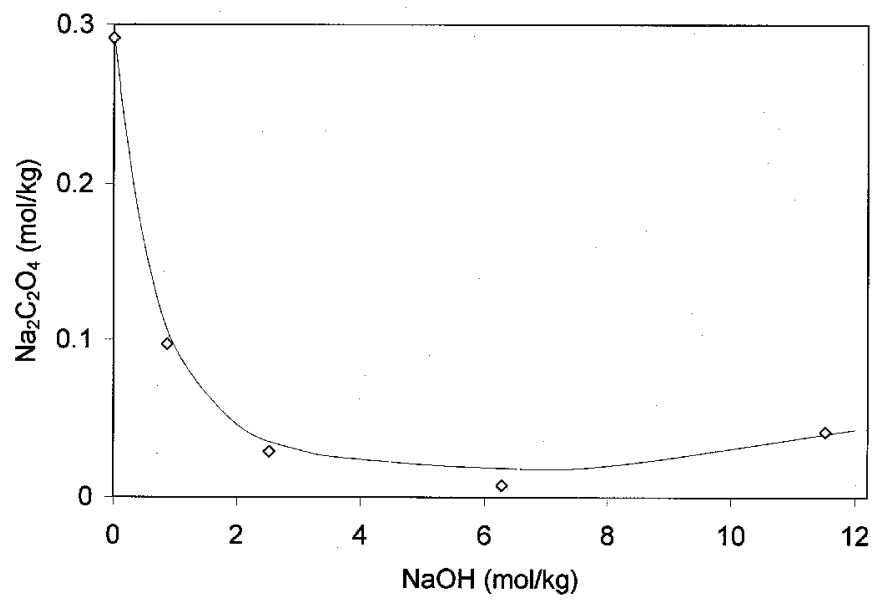

Fig. 23. Solubility of $\mathrm{Na}_{2} \mathrm{C}_{2} \mathrm{O}_{4}$ in $\mathrm{NaOH}$ solutions at $30^{\circ} \mathrm{C}$. $\diamond$ Data from ref. 31 . - Calculations.

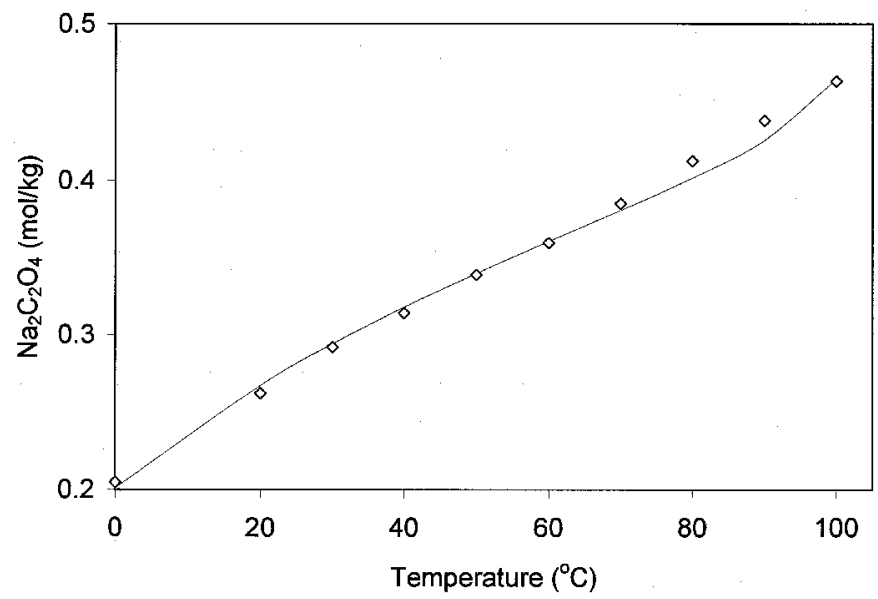

Fig. 25. Solubility of $\mathrm{Na}_{2} \mathrm{C}_{2} \mathrm{O}_{4}$ in water. $\diamond$ Data from ref. 31. Calculations. 


\subsection{Silicates, Aluminates and Aluminosilicates}

The SOLGASMIX model of systems containing aluminum and silicon have recently been documented in a separate report. ${ }^{38}$ While the emphasis in that other work was on lower temperature applications (less than $80^{\circ} \mathrm{C}$ ), it was developed to be consistent with the higher temperature applications relevant to the SRS evaporator. Several of the results and predictions will be shown in the next section, and compared with data and calculations using Geochemists Workbench. ${ }^{3}$

The SOLGASMIX model of silicates includes solubility of amorphous silica and formation of polymeric silicate ions. It is consistent with solubility data and NMR data through the temperature range $25-100^{\circ} \mathrm{C}$ and in concentrations of several molal in both total silicate and $\mathrm{NaOH}$. The aluminate model is derived from the results of Wesolowski. ${ }^{39}$ It includes the aqueous aluminate ion and solubility of gibbsite throughout the temperature range $0-100^{\circ} \mathrm{C}$. Two aluminosilicate solids are included in the SOLGASMIX model, hydroxy-sodalite and nitrate-cancrinite. (The latter has been detected as a major constituent in SRS evaporator deposits.) While there are many metastable aluminosilicate solids, these two form representative solids that are able to successfully predict a wide variety of solubility data. 


\section{VERIFICATION AND DISCUSSION}

The parameters in Appendix A define the SOLGASMIX model for calculation of phase equilibria in electrolyte solutions. Validation is accomplished by the ability of the model to match experimental data. At a minimum, the model should match the data used to regress model parameters. This has generally been the case, as has been demonstrated in Sect. 3. In addition, it should match other data on different systems, which may not have been used directly to obtain model parameters.

In addition to calculations with the SOLGASMIX model, some of the comparisons in this section also include calculations using the code Geochemists Workbench $(\mathrm{GWB}){ }^{3}$ This code has been developed for geochemistry applications at the University of Illinois, and utilized by SRS personnel for preliminary evaluations of tank saturation and evaporator phase equilibria. ${ }^{40}$ It comes with an extensive database for many minerals and aqueous species. SRS personnel have supplemented this database by addition of several aluminosilicate solids. Temperature coefficients are given throughout the range of interest for evaporator applications. However, the primary GWB database relies on the B.dot method for calculating activity coefficients, which may not be adequate for the ionic strengths encountered in SRS wastes.

\subsection{Comparison for Simple Systems}

It is helpful to compare code calculations in simple systems, since these allow more careful identification of discrepancies and difficulties; hence, the two systems $\mathrm{Na}-\mathrm{Al}(\mathrm{OH})_{4}-\mathrm{OH}$ and $\mathrm{Na}_{-} \mathrm{SiO}_{2}-$ $\mathrm{OH}$ are evaluated first. Even though the latter involves a number of polymeric anions, it is still much more straightforward than the complex wastes which contain many different chemical constituents. Furthermore, difficulty in simpler systems will likely lead to discrepancies in more complicated systems.

The solubility of amorphous silica in $\mathrm{NaOH}$ solutions at $25^{\circ} \mathrm{C}$ is shown in Fig. 26, together with predictions by both SOLGASMIX and GWB. Both codes match the data ${ }^{41}$ closely until 
$\mathrm{pH}=10.6$. The GWB prediction then increases very rapidly, departing from the data. Attempts to calculate solubility at higher $\mathrm{Si}$ and $\mathrm{OH}$ levels failed, as the code failed to converge.

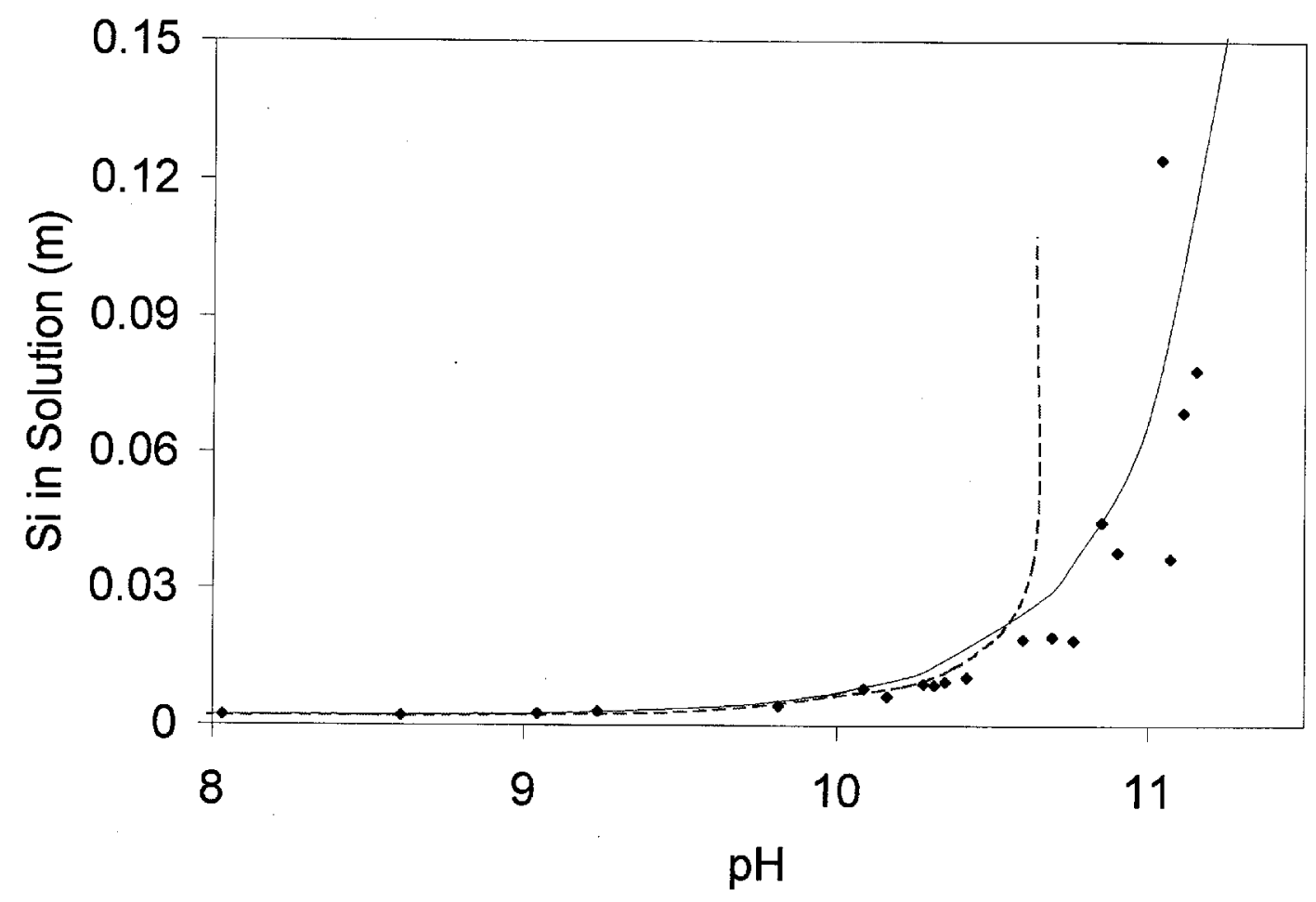

Fig. 26. $\mathrm{SiO}_{2}$ solubility in dilute caustic solutions. Data from ref. 41. Code calculations: - SOLGASMIX, --- GWB.

The solubility of gibbsite in $\mathrm{NaOH}$ solutions is shown in Figs. 27-29 for temperatures $40^{\circ}$, $70^{\circ}$, and $100^{\circ} \mathrm{C}$. In all three figures, the SOLGASMIX predictions closely track the data, even to hydroxide concentrations of $6 \mathrm{~m}$. The GWB data set was modified to include improved equilibrium constants for gibbsite solubility. ${ }^{42}$ However, it is able to follow the data only up to hydroxide levels of about $0.5 \mathrm{~m}$. At higher caustic concentrations, the GWB calculation deviates considerably, likely due to the inadequacy of the B·dot method for calculating activity coefficients. 
It should be noted that the experimental points shown in Figs. 26-29 are some of the data used to regress the SOLGASMIX model parameters. Thus, the SOLGASMIX model is expected to predict these values well. Such is not the case in the following sections, where none of the data were used in model development.

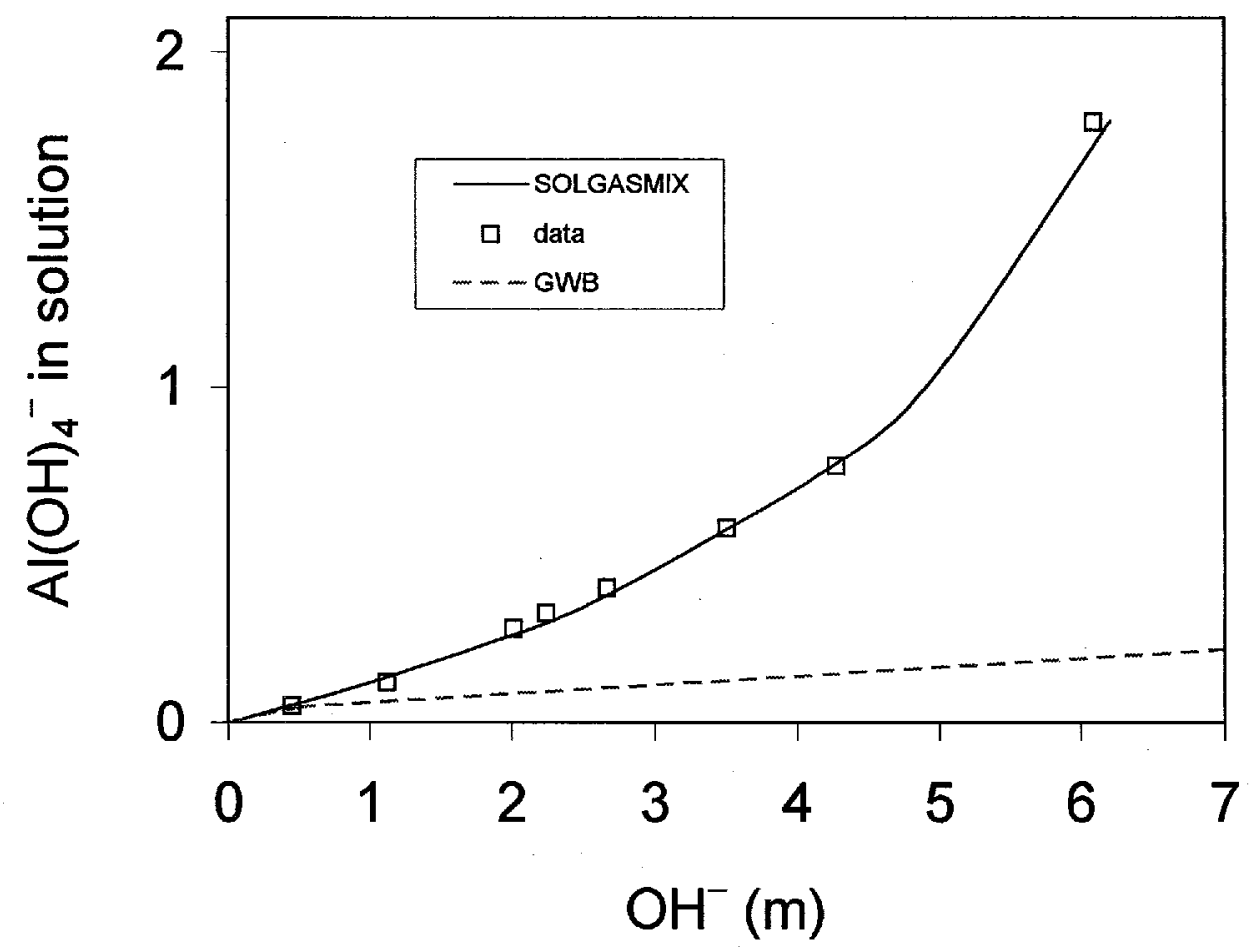

Fig. 27. Gibbsite solubility in caustic solutions at $40^{\circ} \mathrm{C}$. $\square$ Data from ref. 39. Calculations: — SOLGASMIX, --- GWB. 


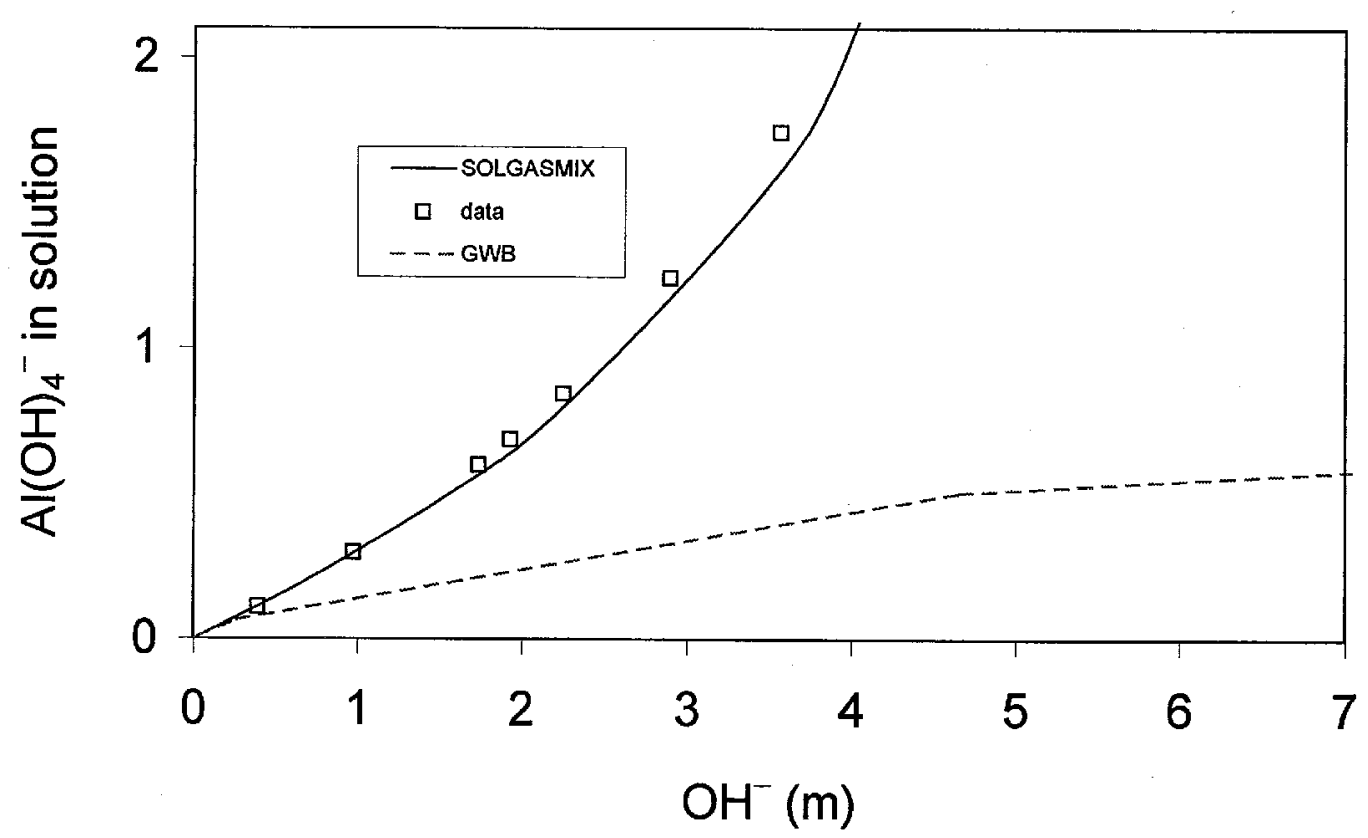

Fig. 28. Gibbsite solubility in caustic solutions at $70^{\circ} \mathrm{C} . \square$ Data from ref. 39. Calculations: - SOLGASMIX, --- GWB.

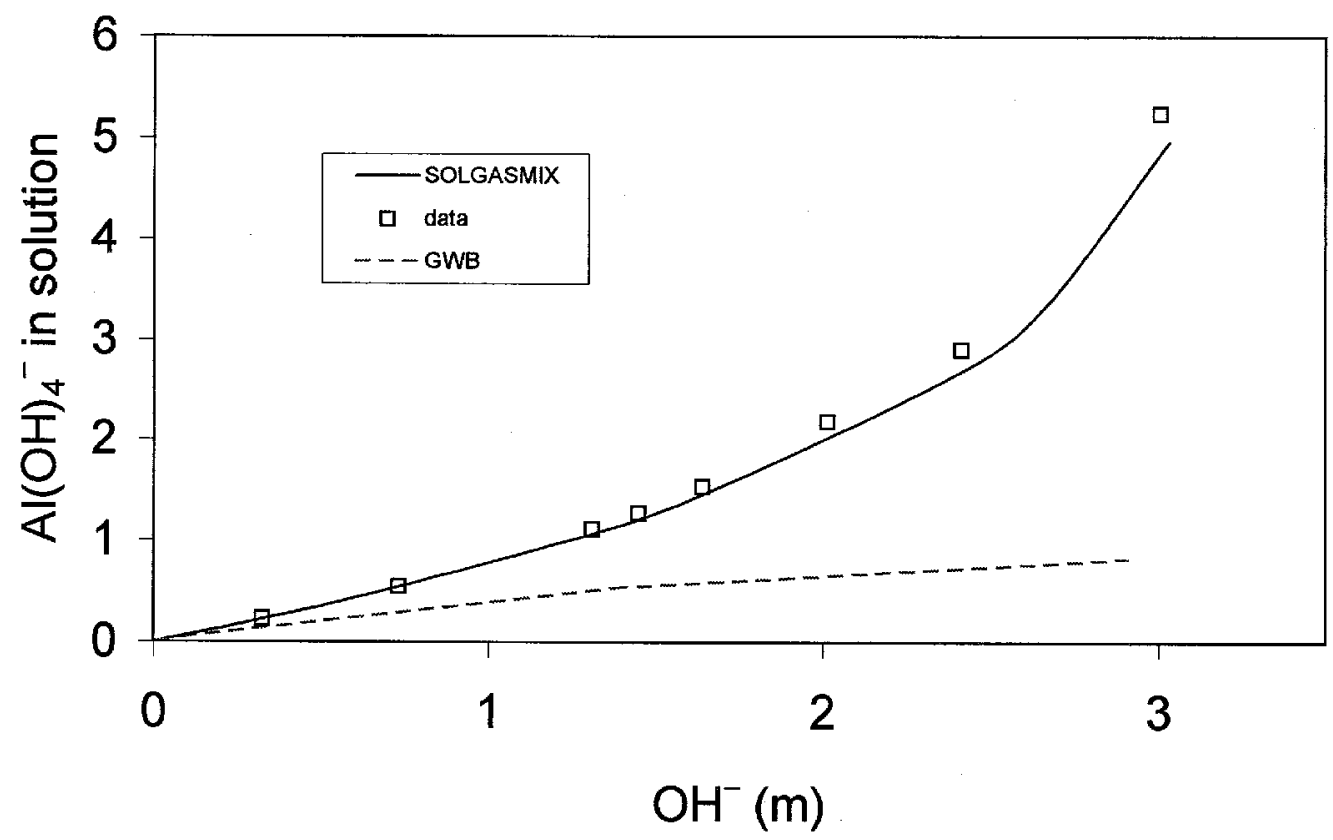

Fig. 29. Gibbsite solubility in caustic solutions at $100^{\circ} \mathrm{C}$. $\square$ Data from ref. 39. Calculations: - SOLGASMIX, --- GWB. 


\subsection{Comparison in Aluminosilicate Systems}

An ideal opportunity for code verification involves SRS simulant solutions. ${ }^{43}$ These have been formulated to represent tank wastes commonly encountered at Savannah River. There are three different solutions, termed "Average," "High-OH," and "High- $\mathrm{NO}_{3}$," whose exact components can be obtained from ref. 43. In addition, recent aluminosilicate solubility experiments involving all the major components of SRS wastes $\left(\mathrm{Na}-\mathrm{NO}_{3}-\mathrm{NO}_{2}-\mathrm{OH}\right)$ have been conducted. 44 These are also important since they involve higher temperatures, consistent with those found in SRS evaporators. All the experiments discussed in this section are kinetic studies, which evaluate the progression to equilibrium over time. None of these data were used in determining model parameters.

Several kinetic studies have indicated that standard SRS waste simulants may precipitate solids under various conditions. When seeded with gibbsite at room temperature, ${ }^{45}$ both the Average and High- $\mathrm{NO}_{3}$ solutions showed noticeable decreases in soluble aluminum, whereas the High-OH simulant indicated a slight increase. This is consistent with SOLGASMIX model calculations, which predict gibbsite precipitation at $25^{\circ} \mathrm{C}$ for the Average and High- $\mathrm{NO}_{3}$ simulants. This behavior is depicted in Fig. 30, where the symbols indicate transient measurements and solid horizontal lines represent equilibrium predictions. The SOLGASMIX model did not predict such precipitation for the High- $\mathrm{OH}$ case, whose rise in soluble $\mathrm{Al}$ could be explained by simple dissolution of the seed particles. 


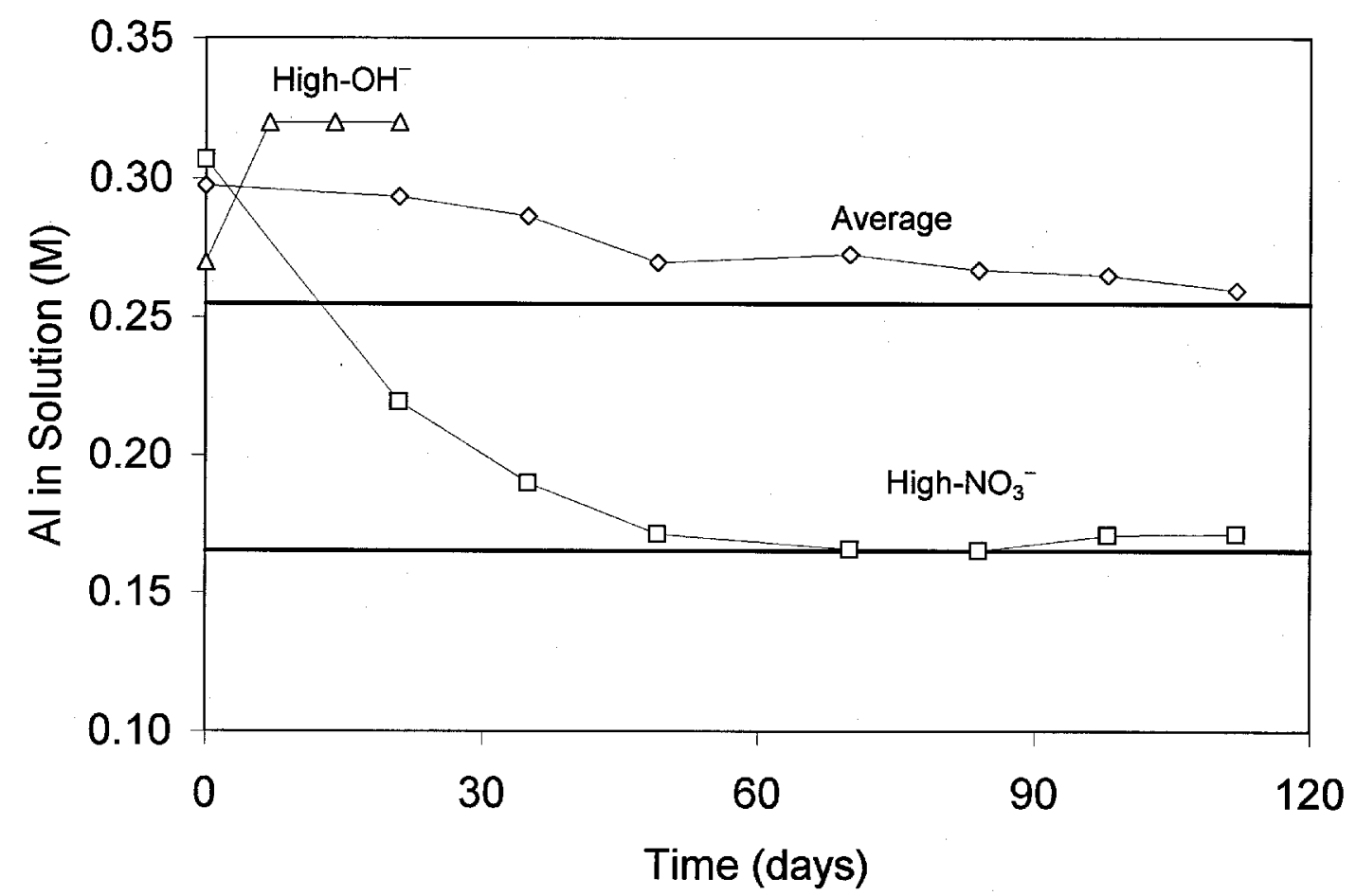

Fig. 30. Precipitation in SRS simulated solutions at $25^{\circ} \mathrm{C}$ (seeded with gibbsite). Data from ref. 45. Solid horizontal lines are SOLGASMIX predictors.

Solutions of SRS Average simulant were evaluated at $55^{\circ}$ and $80^{\circ} \mathrm{C}$ in precipitation studies at Pacific Northwest National Laboratory (PNNL).$_{46}^{46}$ Over time, the concentrations approach steady state values, as shown in Figs. 31 and 32. Both SOLGASMIX and GWB model calculations are also given in the figures as horizontal lines. At both temperatures, the SOLGASMIX predictions are in close agreement with the trend of the data toward equilibrium $\left(\mathrm{NO}_{3}\right.$-cancrinite is the solid phase). The GWB predictions for several different solids are also shown; that for hydroxy-sodalite is closest to the apparent data trend, matching well at $55^{\circ} \mathrm{C}$. All of the solids predicted by GWB are stoichiometrically identical; hence, equilibrium values for the different solids can only be obtained by suppressing (eliminating from calculation) all those whose formation is more favorable. All GWB predictions are somewhat high at $80^{\circ} \mathrm{C}$, and indicate slight increase in solubility as temperature increases. This is in contrast to the SOLGASMIX predictions and the data, where a decrease in solubility occurs with increasing temperature. 


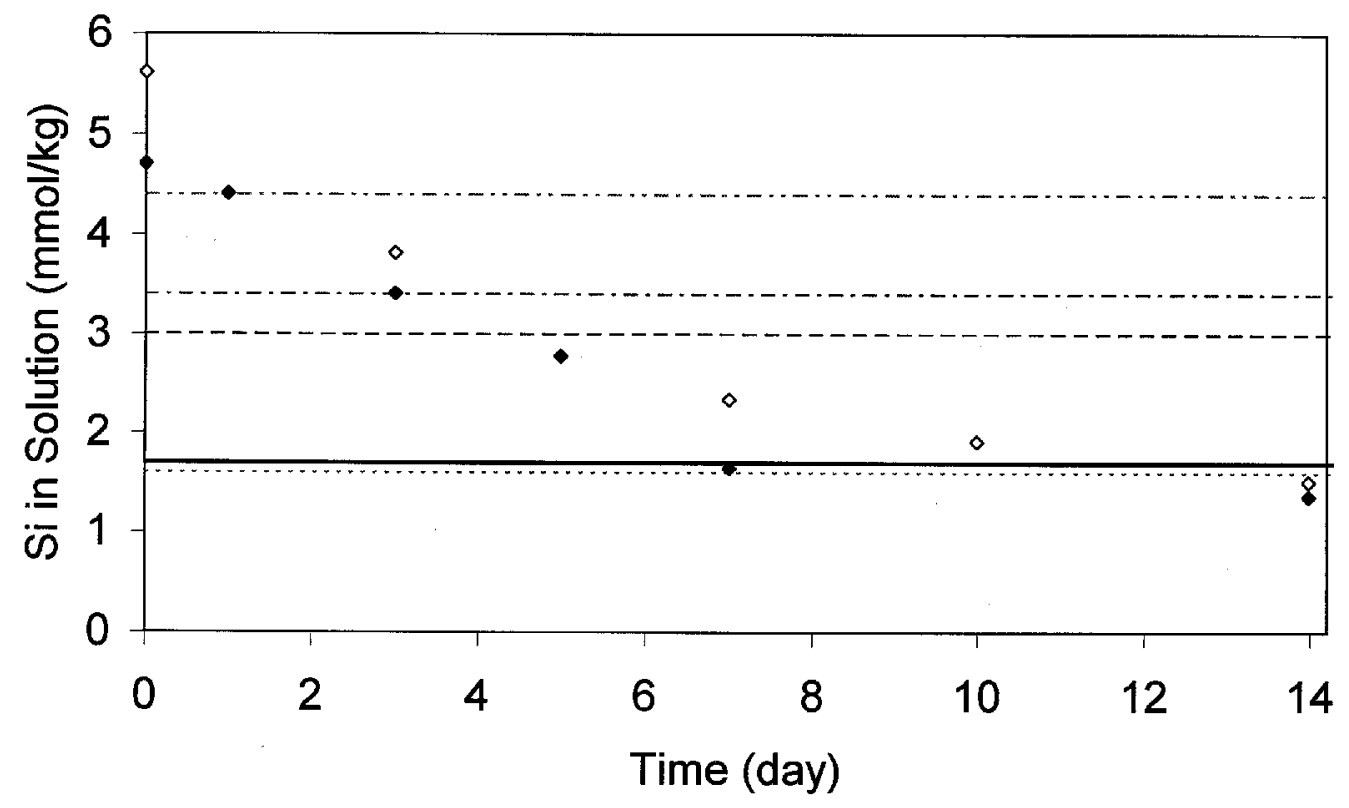

Fig. 31. SRS average simulated at $55^{\circ} \mathrm{C} . \quad \diamond \diamond$ Data from ref. 46 . Calculations: - SOLGASMIX, ‥ GWB (sodalite), --- GWB (zeolite A), - - - . GWB (mixed zeolite), -.. -.. GWB (amorphous aluminosilicate).

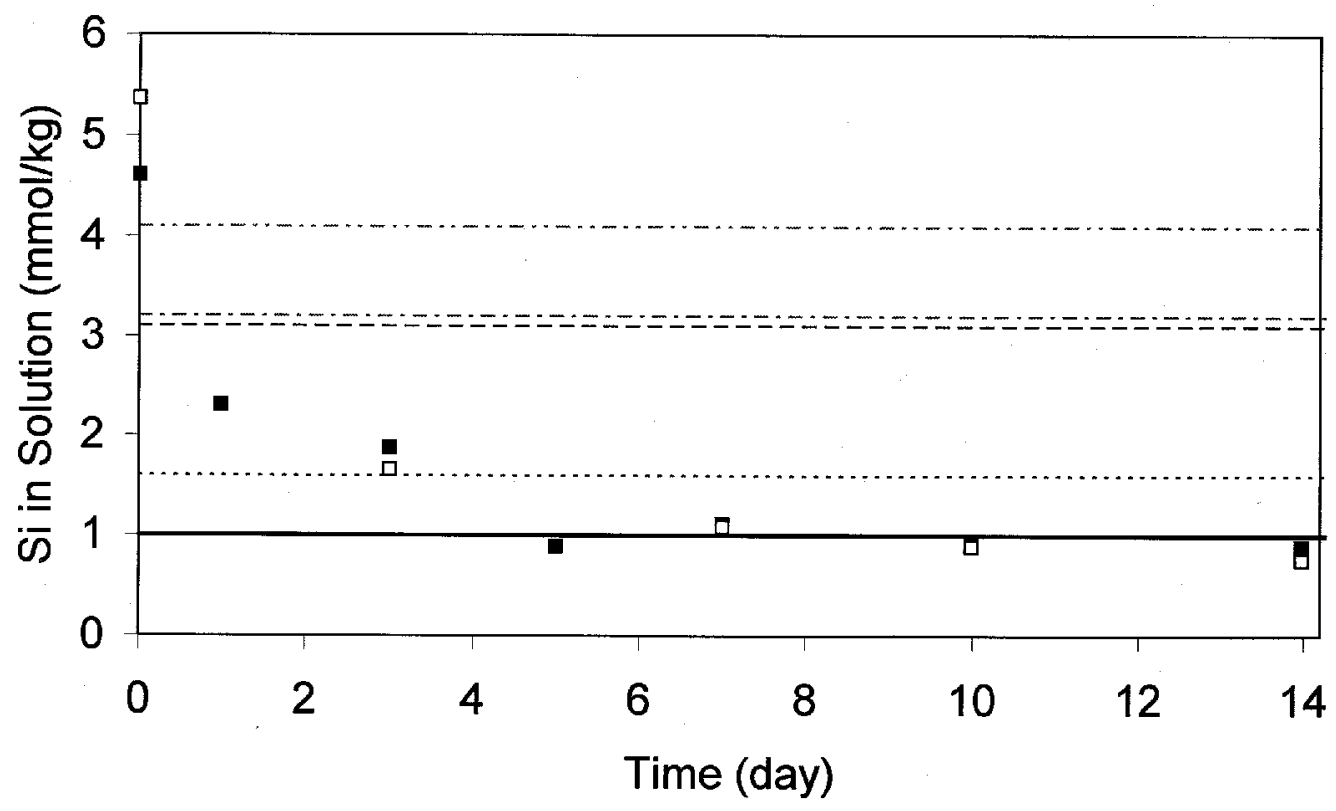

Fig. 32. SRS average simulated at $80^{\circ} \mathrm{C}$. $\square$ Data from ref. 46 . Calculations: SOLGASMIX, $\cdots$ GWB (sodalite), --- GWB (zeolite A), - - - · GWB (mixed zeolite), -.. -.. GWB (amorphous aluminosilicate). 
The SRS High- $\mathrm{NO}_{3}$ simulant was investigated in experiments at Sandia National Laboratory (SNL). The solution was made up at room temperature and its solubility evaluated at six different temperatures. Duplicate silicon measurements were taken and generally agree well with each other. The experimental solubilities are compared with values calculated by SOLGASMIX in Fig. 33. Aluminosilicate was predicted to form above $30^{\circ} \mathrm{C}$ by the model (sodalite at $40^{\circ} \mathrm{C}$, cancrinite at higher temperatures). Also, gibbsite was predicted to form up to $50^{\circ} \mathrm{C}$. The agreement is quite good above $50^{\circ} \mathrm{C}$, although not as close below this temperature. The SNL researchers noted that the experimental system may not have been at equilibrium below $40^{\circ} \mathrm{C}$.

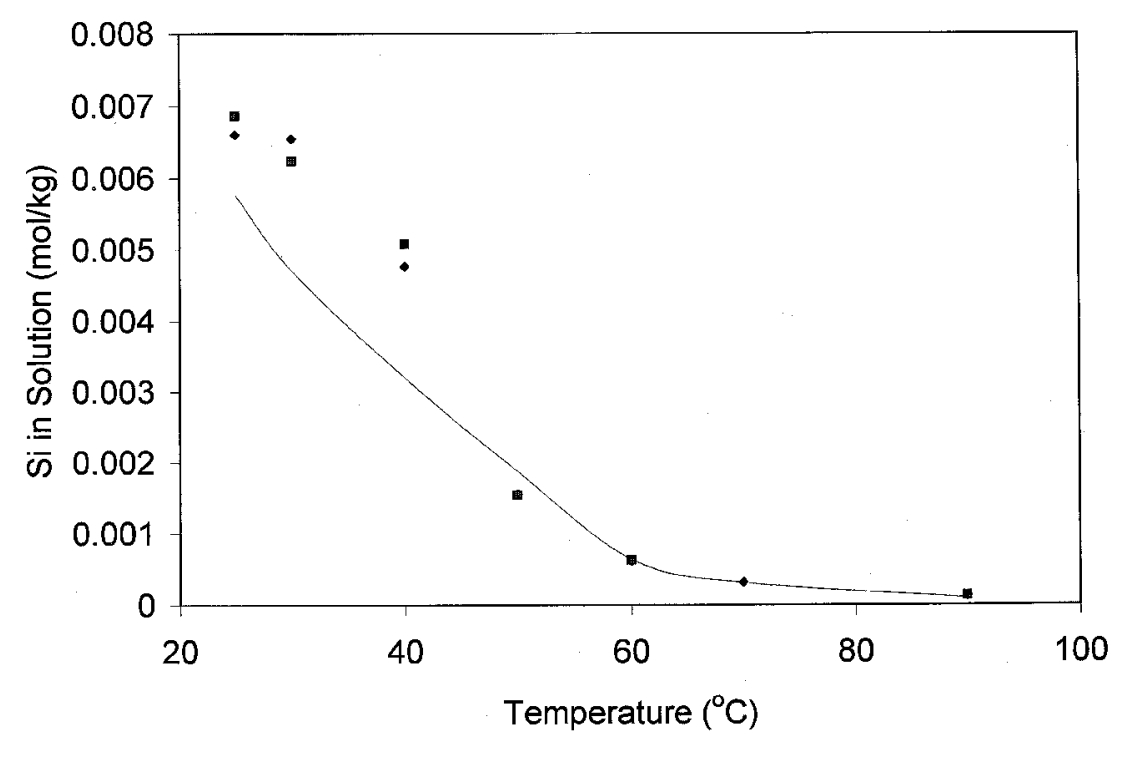

Fig. 33. Precipitation in SRS High- $\mathrm{NO}_{3}$ simulant. $\bullet$ Data from ref. 47. - SOLGASMIX prediction. 
A final comparison involves experiments investigating the transient particle formation and deposition behavior of aluminosilicates. ${ }^{44}$ These data involve the major components of SRS wastes, whose concentrations are listed in Table 1. The experimental data are provided in units of molarity, and solution densities were not measured. Since code calculations require units of mole (or mass) fraction or molality, a density value from ORNL experiments in a similar solution ${ }^{48}$ was used in the conversion. However, the solution densities do change slightly as precipitation occurs throughout the transient; hence, this conversion is only approximate.

Table 1. Components in aluminosilicate formation experiments ${ }^{a}$

\begin{tabular}{lc}
\hline \multicolumn{2}{c}{ Solution density $^{b}$ at $25^{\circ} \mathrm{C}=1.25$} \\
\hline $\mathrm{Compound}$ & Initial Composition $(\mathrm{M})$ \\
\hline $\mathrm{NaOH}$ & 4 \\
$\mathrm{NaNO}_{3}$ & 1 \\
$\mathrm{NaNO}_{2}$ & 1 \\
$\mathrm{Al}\left(\mathrm{NO}_{3}\right)_{2} \cdot 9 \mathrm{H}_{2} \mathrm{O}$ & 0.133 \\
$\mathrm{SiO}_{2}$ & 0.116 \\
\hline
\end{tabular}

${ }^{a}$ From ref. 44.

${ }^{b}$ From ref. 48.

Shown in Figs. 34 and 35 are the transient data at $80^{\circ}$ and $120^{\circ} \mathrm{C}$, together with the SOLGASMIX equilibrium predictions (horizontal lines). The data attain their equilibrium values smoothly, and these values are close to the calculated values. In each case, the predicted solubilities (solid phase was $\mathrm{NO}_{3}$-cancrinate) are slightly higher than the data indicate, although the conversion discussed above (molarity to molality) may account for much of this discrepancy. In any event, the predictions do match the data fairly well, which is encouraging since no data higher than $80^{\circ} \mathrm{C}$ were used during model formulation. It should also be noted that the inverse solubility relationship also holds here - both data and code calculations indicate lower solubility at $120^{\circ}$ than at $80^{\circ} \mathrm{C}$. 


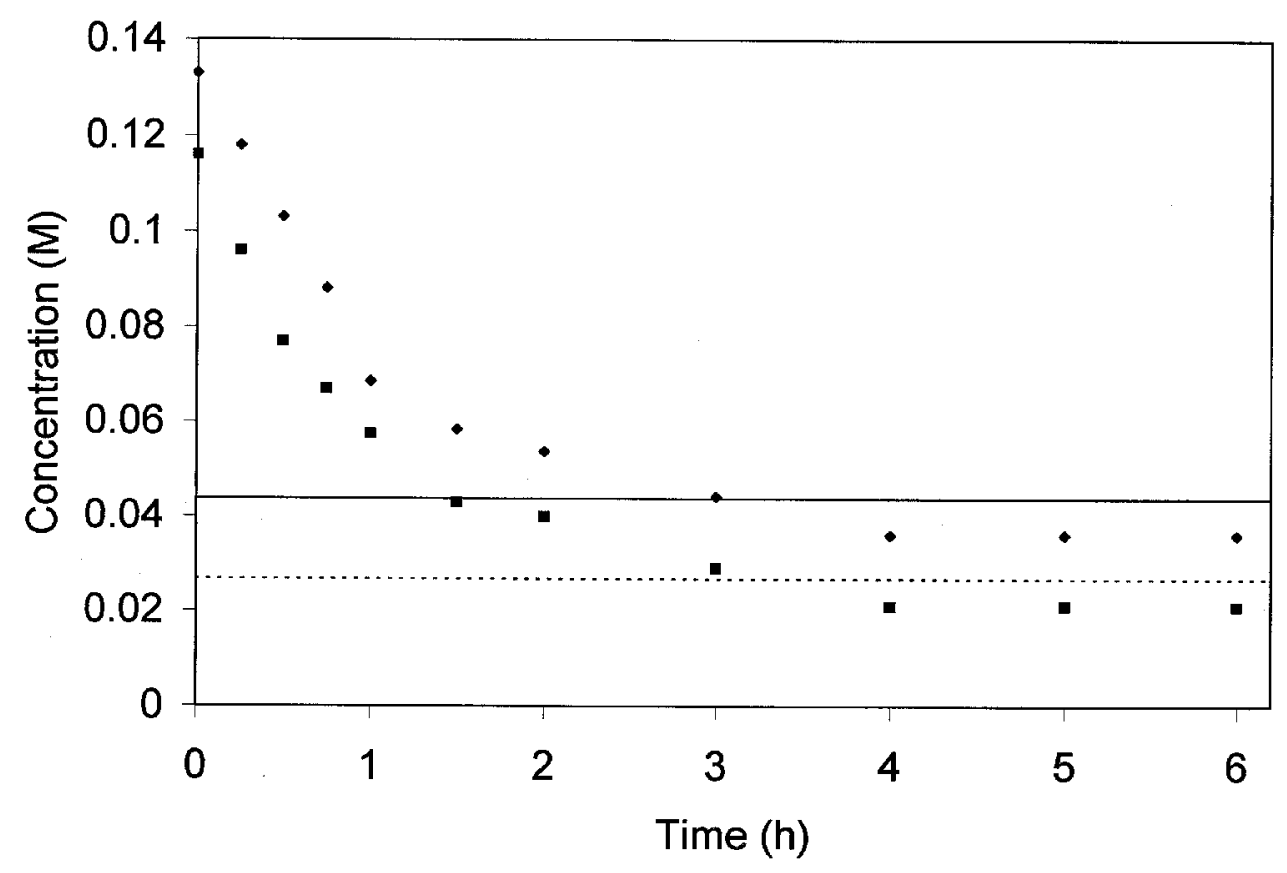

Fig. 34. Cancrinite solubility in nitrate-nitrite-hydroxide solution at $80^{\circ} \mathrm{C}$. Data from ref. 44: Al, $\square$ Si. SOLGASMIX Calculations: — Al, --- Si.

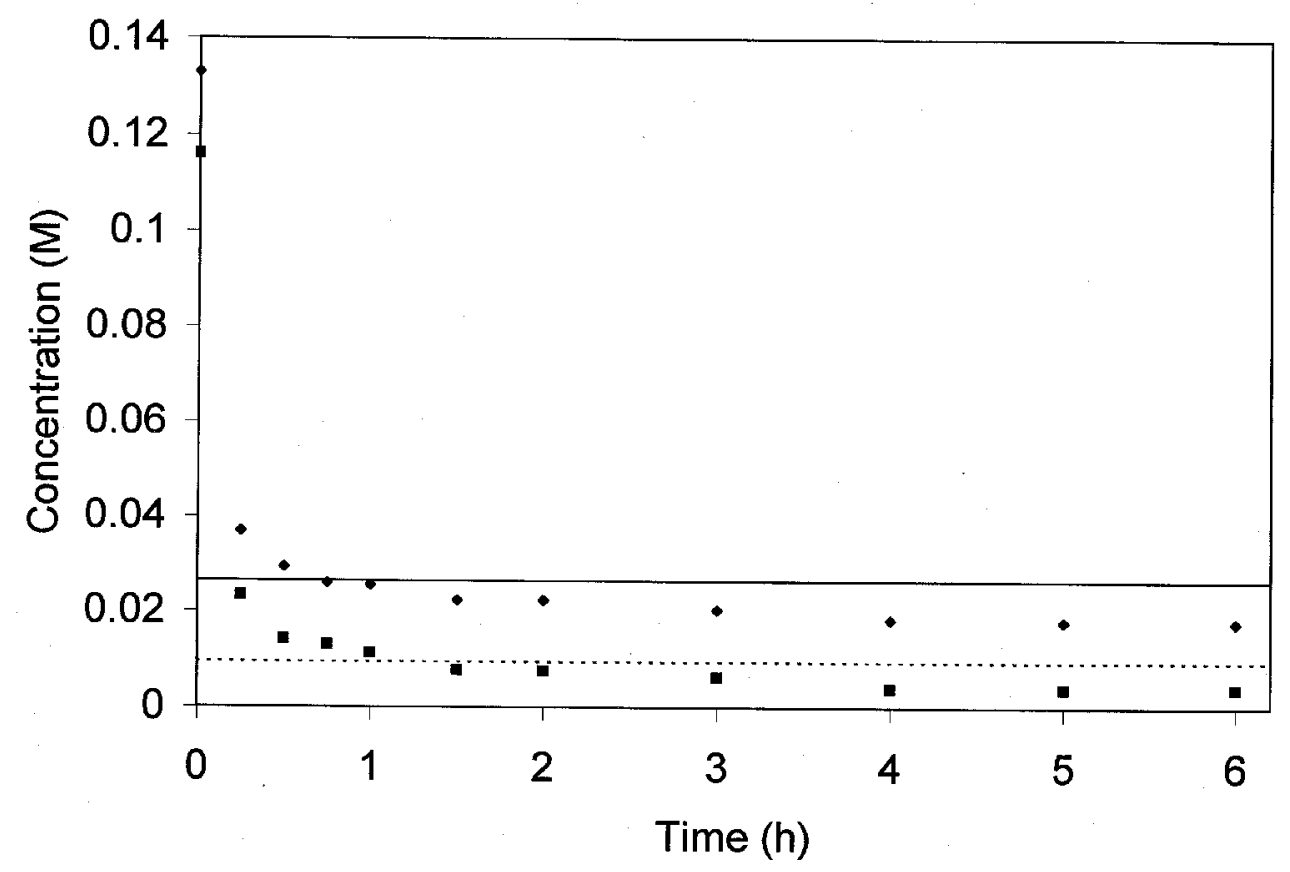

Fig. 35. Cancrinite solubility in nitrate-nitrite-hydroxide solution at $120^{\circ} \mathrm{C}$. Data from ref. 44: Al, $\square$ Si. SOLGASMIX Calculations: — Al, --- Si. 


\subsection{Application to SRS Tanks}

The SOLGASMIX model has been applied to evaluate saturation conditions in various SRS tanks. ${ }^{38}$ A database of tank inventory measurements was supplied by SRS and forms the basis for such evaluations. ${ }^{49}$ In this study, we not only evaluate the tank inventories, but illustrate solubility diagrams by varying the inventories of $\mathrm{Si}$ and $\mathrm{Al}$.

Two tanks are considered - Tanks 43 and 32, both of which are evaporator feed tanks (for $2 \mathrm{H}$ and $3 \mathrm{H}$ evaporators, respectively). Several recent dip samples are obtained for each tank and plotted in Figs. 36 and 37 (note the log scale for concentration units of molality). The solid lines represent SOLGASMIX calculations of the solubility equilibria at $40^{\circ} \mathrm{C}$ (nominal feed temperature). The dashed lines represent the $\mathrm{NO}_{3}$-cancrinite solubility equilibria at evaporator operating temperatures $\left(120^{\circ} \mathrm{C}\right.$ in Fig. 36 and $140^{\circ} \mathrm{C}$ in Fig. 37). These curves were constructed by holding constant all species concentrations except $\mathrm{Al}$ and $\mathrm{Si}$. The inventories of $\mathrm{Al}$ and $\mathrm{Si}$ were varied to determine the point at which precipitation occurs. Any inventories of $\mathrm{Al}$ and $\mathrm{Si}$ above or to the right of the solubility curves indicate solids formation; below and to the left indicate no solids.

The figures for both tanks indicate that no aluminosilicate solids should form at $40^{\circ} \mathrm{C}$. However, both also indicate that solids $\left(\mathrm{NO}_{3}\right.$-cancrinite in each case) should form at evaporator operating temperatures. This is a direct result of the inverse solubility condition - solubility of cancrinite decreases as temperature increases. It is illustrated in Figs. 36 and 37 in that the hightemperature curves are lower than the solubility curves for $40^{\circ} \mathrm{C}$. 


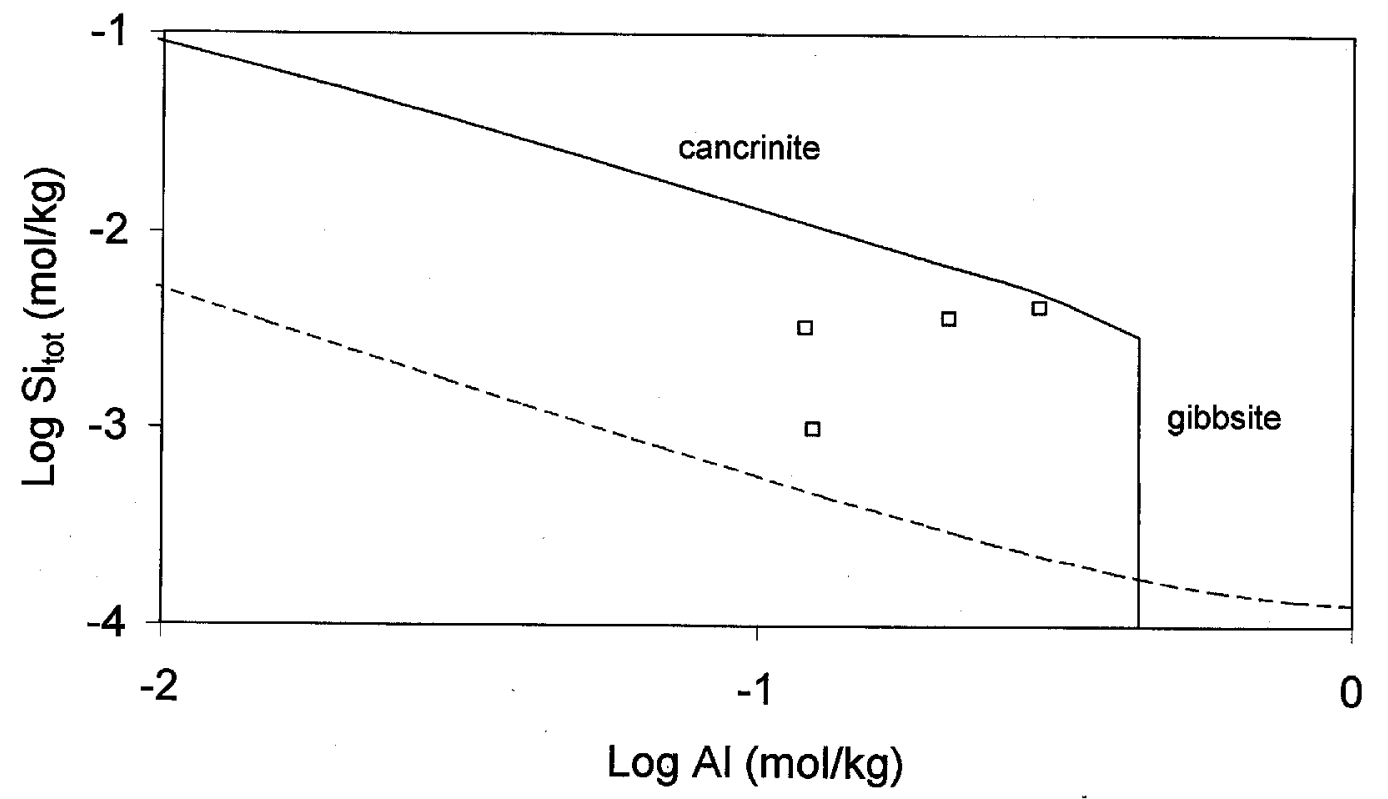

Fig. 36. Solubility diagram for SRS Tank 43. $\square$ Dip samples (12/23/00, 10/18/00, 7/30/00, 5/6/00). Calculated solubility curves: $-40^{\circ} \mathrm{C},--120^{\circ} \mathrm{C}$.

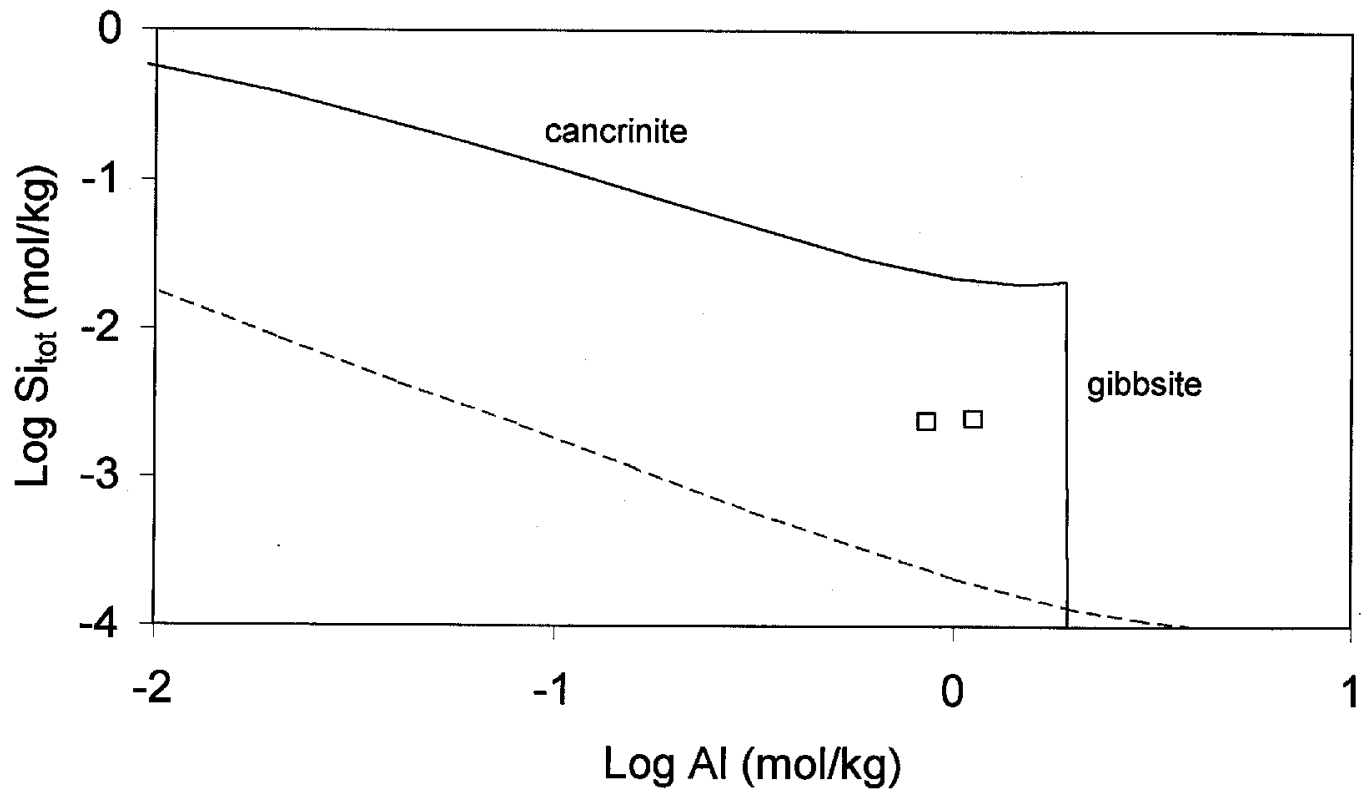

Fig. 37. Solubility diagram for SRS Tank 32 . $\square$ Dip samples $(2 / 15 / 01,12 / 5 / 00)$. Calculated solubility curves: $-40^{\circ} \mathrm{C},---140^{\circ} \mathrm{C}$. 


\section{SUMMARY AND CONCLUSIONS}

A thermodynamic model based on the SOLGASMIX code has been developed which simulates phase equilibrium of SRS wastes within the temperature range $25-125^{\circ} \mathrm{C}$. This model has been validated by comparing calculated solubilities to experimental data throughout this temperature range. Additional calculations using the Geochemists Workbench (GWB) code are compared to SOLGASMIX results and experimental solubilities. In some cases, the GWB results make poor predictions, due largely to the inadequacy of the B·dot model for activity coefficients.

The SOLGASMIX model uses the Pitzer method for calculation of activity coefficients, and minimization of Gibbs energy to calculate equilibrium species distributions. A number of the needed parameters have been obtained as a part of this work through nonlinear regression of data. Many of these parameters were determined throughout the desired temperature range; others involved data up to $100^{\circ} \mathrm{C}$, and can reliably be extrapolated somewhat higher. The validity of the model has been established by predictions that closely match thermodynamic data, including data not used to obtain model parameters.

The SOLGASMIX model was used to predict precipitations in SRS waste simulants at 25, 55 , and $80^{\circ} \mathrm{C}$. The predictions at all three temperatures were consistent with measurements, although the calculated solubilities were slightly higher than the data. Predictions of aluminosilicate solubilities in $\mathrm{Na}-\mathrm{NO}_{3}-\mathrm{NO}_{2}-\mathrm{OH}$ solutions were quite consistent with kinetic data trends at 80 and $120^{\circ} \mathrm{C}$. The code calculations reflected decreasing aluminosilicate solubility with increasing temperature, consistent with all the data.

The GWB model was able to predict amorphous silica solubilities quite well below $\mathrm{pH}=10.6$, although the code had convergence problems above this value. It gave poor results in predicting gibbsite solubility at ionic strengths above $0.5 \mathrm{M}$. The prediction of sodalite solubility was close to data at $55^{\circ} \mathrm{C}$, although it demonstrated increasing solubility as temperature increases, contrary to data. 
We anticipate additional revision and improvement of the SOLGASMIX model as new data become available. Some simple experiments at ORNL will hopefully yield solubilities of amorphous $\mathrm{SiO}_{2}$ in solutions containing $\mathrm{NaOH}$ and $\mathrm{NaNO}_{3}$ and at higher temperatures. This will allow a more complete description of interactions between silicate anions and $\mathrm{NO}_{3}^{-}$ions. Currently, no such data exist. Current research at SRS and PNNL is designed to measure aluminosilicate speciation and solubilities in solutions containing both $\mathrm{NaNO}_{3}$ and $\mathrm{NaOH}$. Such data may indicate presence of soluble Al-Si polymeric ions, and will provide more quantitative data for solubility of hydroxysodalite and nitrate-cancrinite (and possibly other solids as well). 


\section{REFERENCES}

1. G. Eriksson, "Thermodynamic Studies of High Temperature Equilibria. XII. SOLGASMIX, A Computer Program for Calculation of Equlibrium Compositions in Multiphase Systems," Chemica Scripta 8, 100 (1975).

2. C. F. Weber, "Convergence of the Equilibrium Code SOLGASMIX," J. Comp. Phys. 145, 655 (1998).

3. C. M. Bethke, The Geochemists Workbench, Release 3.0, Hydrogeology Program, University of Illinois (1998).

4. J. V. Beck and K. J. Arnold, Parameter Estimation in Engineering and Science, Wiley, New York (1977).

5. J. H. Seinfeld and L. Lapidus, Mathematical Methods in Chemical Engineering, Vol. 3, Prentice-Hall, Englewood Cliffs, New Jersey (1974).

6. R. Fletcher, Practical Methods of Optimization, Wiley, New York (1987).

7. HSC Chemistry for Windows, Version 2.0, Outokumpu Research, May 31, 1994.

8. D. Garvin, V. B. Parker, and H. J. White, CODATA Thermodynamic Tables, Hemisphere, Wash., 1987.

9. $\quad$ K. S. Pitzer, "Thermodynamics of Electrolytes. I. Theoretical Basis and General Equations," J. Phys. Chem. 77, 268 (1973).

10. K. S. Pitzer, "Ion Interaction Approach: Theory and Data Correlation," in K. S. Pitzer, ed., Activity Coefficients in Electrolyte Solutions, $2^{\text {nd }}$ Ed., CRC Press, Boca Raton, Florida (1991).

11. C. E. Harvie, N. Moller, and H. H. Weare, "The Prediction of Mineral Solubilities in Natural Waters: The $\mathrm{Na}-\mathrm{K}-\mathrm{Mg}-\mathrm{Ca}-\mathrm{H}-\mathrm{Cl}-\mathrm{SO}_{4}-\mathrm{OH}-\mathrm{HCO}_{3}-\mathrm{CO}_{3}-\mathrm{CO}_{2}-\mathrm{H}_{2} \mathrm{O}$ System to High Ionic Strengths at $25^{\circ} \mathrm{C}, "$ Geochim. Cosmochim. Acta 48, 723 (1984).

12. G. Scatchard, S. S. Prentiss, and P. T. Jones, "The Freezing Point of Aqueous Solutions. II. Potassium, Sodium and Lithium Nitrates," J. Amer. Chem. Soc. 54, 2690-5 (1932).

13. W. Voigt, A. Dittrich, B. Haugsdal, and K. Grjotheim, "Thermodynamics of Aqueous Reciprocal Salt Systems. II. Isopiestic Determination of the Osmotic and Activity 
Coefficients in $\mathrm{LiNO}_{3}-\mathrm{NaBr}-\mathrm{H}_{2} \mathrm{O}$ and $\mathrm{LiBr}-\mathrm{NaNO}_{3}-\mathrm{H}_{2} \mathrm{O}$ at $100.3^{\circ} \mathrm{C}, "$ Acta. Chem. Scand. 44, 12-17 (1990).

14. CRC Handbook of Chemistry and Physics, $59^{\text {th }}$ Ed. (1978).

15. W. E. Forsythe, Ed., Smithsonian Physical Tables, $9^{\text {th }}$ Ed., Smithsonian Institution, Washington (1954); also found in CRC Handbook of Chemistry and Physics, $59^{\text {th }}$ Ed. (1978).

16. L. Shpigel and K. P. Mischenko, "Activities and Rational Activity Coefficients of Water in Potassium Nitrate and Sodium Nitrate Solutions at 1, 25, 50, and $70^{\circ}$ over a Wide Concentration Range," Russ. J. Appl. Chem. 40(3), 659-61 (1967).

17. Y. C. Wu and W. J. Hamer, "Revised Values of the Osmotic Coefficients and Mean Activity Coefficients of Sodium Nitrate in Water at $25^{\circ}$ C," J. Phys. Chem. Ref. Data 9(2), 513-8 (1980).

18. Th. Fanghamel, K. Grjotheim, W. Voigt, and V. Brendler, "Thermodynamics of Reciprocal Salt Systems. VI. Isopiestic Determination of Osmotic Coefficients in Mixtures of Chlorides, Bromides, and Nitrates of Lithium, Sodium, Potassium, and Cesium at $100.3^{\circ} \mathrm{C}, "$ Acta. Chem. Scand. 46, 423-31 (1992).

19. W. J. Hamer and Y-C. Wu, "Osmotic Coefficients and Mean Activity Coefficients of Uni-univalent Electrolytes in Water at $25^{\circ} \mathrm{C}, "$ J. Phys, Chem. Ref. Data 1(4), 1047-99 (1972).

20. H. S. Harned and M. A. Cook, "The Thermodynamics of Aqueous Potassium Hydroxide Solutions from Electromotive Force Measurements," J. Amer. Chem. Soc. 59, 496-500 (1937).

21. G. C. Akerlof and P. Bender, "Thermodynamics of Aqueous Solutions of Potassium Hydroxide," J. Amer. Chem. Soc. 70, 2366-9 (1948).

22. J. Balej, "Water Vapor Partial Pressures in Potassium and Sodium Hydroxide Solutions Over Wide Concentration and Temperature Ranges," Int. J. Hydrogen Energy 10(4), 233-43 (1985).

23. B. R. Staples, "Activity and Osmotic Coefficients of Aqueous Alkali Metal Nitrites," J. Phys. Chem. Ref. Data 10(3), 765 (1981). 
24. N. P. Chekhunova and P. I. Protsenko, "Activity Coefficients of the Nitrites of Sodium, Potassium, and Magnesium," Russ. J. Phys. Chem. 41(9), 1220 (1967).

25. S. M. Sterner, J. R. Rustad, A. R. Felmy, The Hanford Thermochemical Databank: v 1.00 With Parameters for the ESP and Pitzer Models, PNL-SA-23952 (CONF-9408168-3), Pacific Northwest Laboratory (1996).

26. A. Apelblat and E. Korin, "The Vapor Pressures of Saturated Aqueous Solutions of SodiumChloride, Sodium-Bromide, Sodium Nitrate, Sodium Nitrite, Potassium Iodate, and Rubidium Chloride at Temperatures from $227 \mathrm{~K}$ to 323 K," J. Chem. Thermo. 30, 59-71 (1998).

27. D. D. Wagman et al., "The NBS Tables of Chemical Thermodynamic Properties," J. Phys. Chem. Ref. Data 11, Supplement 2 (1982).

28. J. D. Ray and R. A. Ogg, "The Anomalous Entropy of Potassium Nitrate," J. Phys. Chem. 60, 1599 (1956).

29. International Critical Tables, Vol. IV, 259, McGraw-Hill, New York (1928).

30. W. F. Linke, Solubilities, $4^{\text {th }}$ ed., Vol. II, D. Van Nostrand Co., Princeton, New Jersey (1958).

31. W. H. Norris, "The System Oxalic Acid-Sodium Hydroxide-Water," J. Chem. Soc., 1708 (1951).

32. M. I. Zhikharev, V. I. Kol'ba, and L. P. Sukhanov, "The $\mathrm{Na}_{2} \mathrm{C}_{2} \mathrm{O}_{4}-\mathrm{NaNO}_{3}-\mathrm{H}_{2} \mathrm{O}$ System at $20^{\circ}$ C," Russ. J. Inorg. Chem. 24(3), 469 (1979).

33. V. I. Kol'ba, M. I. Zhikharev, and L. P. Sukhanov, "The $\mathrm{Na}_{2} \mathrm{C}_{2} \mathrm{O}_{4}-\mathrm{NaNO}_{3}-\mathrm{H}_{2} \mathrm{O}$ System at $50^{\circ}$ and $75^{\circ} \mathrm{C}, "$ Russ. J. Inorg. Chem. 25(10), 1583 (1980).

34. M. A. Colani, "Solubilité des oxalates alcalins en présence de quelques sels alcalins," Bull. Soc. Chim. France (Ser. 4) 19, 405 (1916).

35. J. R. Fowler, Effect of Temperature on Sodium Oxalate Solubility, technical memo to J. R. Wiley, DIST.-80-265, Technical Division, Savannah River Laboratory (Feb. 22, 1980).

36. J. R. Wiley, Sodium Oxalate Solubility in Simulated SRS Waste Solutions, Memorandum to M. L. Hoder, DIST.-78-480, Technical Division, Savannah River Laboratory (Aug. 23, 1978). 
37. G. S. Barney, The Solubilities of Significant Organic Compounds in HOW Tank Supernate Solutions - FY1997 Progress Report, WHC-DP-0899-2, Westinghouse Hanford Co. (1997).

38. C. F. Weber, Phase Equilibrium Studies of Savannah River Tanks and Feed Streams for the Salt Waste Processing Facility, ORNL/TM-2001/109, UT-Battelle, LLC, Oak Ridge National Laboratory (2001).

39. D. J. Wesolowski, "Aluminum Speciation and Equilibria in Aqueous Solution: I. The Solubility of Gibbsite in the System Na-K-Cl-OH-Al(OH)$)_{4}$ from 0 to $100^{\circ} \mathrm{C}$," Geochim. Cosmochim. Acta 56, 1065 (1992).

40. C. M. Jantzen and J. E. Laurinat, Application of Thermodynamic Activity Diagrams to the Prediction of Solids Formation in the Savannah River Site (SRS) 3 H Evaporator, WSRCTR-2001-00155, Westinghouse Savannah River Company (2001).

41. G. B. Alexander, W. M. Heston, and R. K. Iler, "The Solubility of Amphorous Silica in Water," J. Phys. Chem. 58, 453 (1954).

42. C. M. Jantzen and J. E. Laurinat, Application of Thermodynamic Activity Diagrams: Prediction of Solids Formation in the SRS $2 \mathrm{H}$ and $3 \mathrm{H}$ Evaporators, presentation at the Savannah River Zeolite Workshop, June 6-7, 2001.

43. D. D. Walker, Preparation of Simulant Waste Solutions, WSRC-TR-99-00116 (1999).

44. J. Addai-Mensah, Sodium Aluminosilicate Scale Formation in Westinghouse Savannah River Company 2 H Evaporation Process, Subcontract No. AC181065, Report No. 1 (May 18, 2001).

45. D. D. Walker, personal communication via e-mail (March 2001).

46. Y. Su, L. Li, J. S. Young, and M. L. Balmer, Investigation of Chemical and Thermal Stabilities of Cs-Loaded UOP IONSIV ${ }^{\circledR} I E-911$ Ion Exchange (Final Report), PNNL-133922, Pacific Northwest National Laboratory (March, 2001).

47. J. L. Krumhansl, e-mail to C. F. Weber (April 23, 2001).

48. M. Z. Hu, D. W. DePaoli, and D. T. Bostick, Dynamic Particle Growth Testing, Phase I Studies, ORNL/TM-2001/100, UT-Battelle, LLC, Oak Ridge National Laboratory (2001).

49. Jeff Pike, e-mail to C. F. Weber (March 28, 2001). 
50. C. F. Weber, E. C. Beahm, and J. S. Watson, "Modeling Thermodynamics and Phase Equilibria for Aqueous Solutions of Trisodium Phosphate," J. Soln. Chem. 28(11), 1207 (1999).

51. C. F. Weber, E. C. Beahm, D. D. Lee, and J. S. Watson, "A Solubility Model for Aqueous Solutions Containing Sodium, Fluoride, and Phosphate Ions," Ind. Eng. Chem. Res. 39, 518-26 (2000).

52. R. D. Hunt et al., Waste Preparation and Transport Chemistry: Results of the FY2000 Studies, ORNL/TM-2000/298, U.T. Battelle, LLC, Oak Ridge National Laboratory (2000).

53. D. T. Hobbs and D. G. Karraker, "Recent Results on the Solubility of Uranium and Plutonium in Savannah River Waste Supernate," Nucl. Technol. 114, 318-24 (1996); K. H. Gayer and H. Leider, "The Solubility of Uranium Trioxide, $\mathrm{UO}_{3} \cdot \mathrm{H}_{2} \mathrm{O}$, in Solutions of Sodium Hydroxide and Perchloric Acid at 25," J. Am. Chem. Soc. 77, 1448-50 (1955).

54. B. Toghiani et al., Modeling of Sulfate Double-Salt in Nuclear Wastes, ORNL/TM2000/317, UT-Battelle, LLC, Oak Ridge National Laboratory (2000).

55. S. He and J. W. Morse, "The Carbonic Acid System and Calcite Solubility in Aqueous $\mathrm{Na}-\mathrm{K}-\mathrm{Ca}-\mathrm{Mg}-\mathrm{Cl}-\mathrm{SO}_{4}$ solutions from 0 to $90^{\circ} \mathrm{C}$, "Geochim. Cosmochim. Acta 57, 3533-54 (1993).

56. C. F. Weber and E. C. Beahm, Chemical Modeling of Waste Sludges, ORNL/TM-13200, Lockheed Martin Energy Research Corp., Oak Ridge National Laboratory (1996).

57. J. C. Peiper and K. S. Pitzer, "Thermodynamics of Aqueous Carbonate Solutions Including Mixtures of Sodium Carbonate, Bicarbonate, and Chloride," J. Chem. Thermodyn. 14, 613 (1982). 


\section{APPENDIX A}


Table A.1. Coefficients for Gibbs Energy of Formation $\mu^{0} / \mathrm{RT}=\mathrm{A}+\mathrm{B}\left(\mathrm{T}-\mathrm{T}_{0}\right)+\mathrm{C}\left(1 / \mathrm{T}_{0}-1 / \mathrm{T}\right)+\mathrm{D} \ln \left(\mathrm{T} / \mathrm{T}_{0}\right)+\mathrm{E}\left(\mathrm{T}^{2}-\mathrm{T}_{0}^{2}\right)$

\begin{tabular}{|c|c|c|c|c|c|c|}
\hline & A & B & $\mathrm{C}$ & $\mathrm{D}$ & $\mathrm{E}$ & Ref. $^{a}$ \\
\hline $\mathrm{Ar}$ & 0 & 0 & 0 & 0 & 0 & \\
\hline $\mathrm{H}_{2} \mathrm{O}$ & -95.667 & 0 & 35520.58 & -3.82631 & 0 & 7 \\
\hline $\mathrm{Na}^{+}$ & -105.642 & 0 & 29203.98 & -1.16439 & 0 & 7 \\
\hline $\mathrm{K}^{+}$ & -113.968 & 0 & 29220.3 & 3.731026 & 0 & 7 \\
\hline $\mathrm{H}^{+}$ & 0 & 0 & 0 & 0 & 0 & \\
\hline $\mathrm{UO}_{2}^{2+}$ & -384.629 & 0 & 131094.3 & -28.2168 & 0 & 7 \\
\hline $\mathrm{NO}_{3}^{-}$ & -44.707 & 0 & 20337.25 & 15.17588 & 0 & 7 \\
\hline $\mathrm{OH}^{-}$ & -63.446 & 0 & 21972.73 & 19.03521 & 0 & 7 \\
\hline $\mathrm{Cl}^{-}$ & -52.951 & 0 & 14731.27 & 17.92967 & 0 & 7 \\
\hline $\mathrm{F}^{-}$ & -113.643 & 0 & 35464.6 & 16.25967 & 0 & 7 \\
\hline $\mathrm{PO}_{4}^{3-}$ & -410.766 & 0 & 132983.5 & 69.11808 & 0 & 7 \\
\hline $\mathrm{HPO}_{4}^{2-}$ & -439.166 & 0 & 174154.1 & -60.0832 & 0 & 50 \\
\hline $\mathrm{NO}_{2}^{-}$ & -12.931 & 0 & 7624.179 & 16.5833 & 0 & 7 \\
\hline $\mathrm{Al}(\mathrm{OH})_{4}^{-}$ & -526.779 & 0 & 180307.3 & 0.842528 & 0 & 39 \\
\hline $\mathrm{CO}_{3}^{2-}$ & -212.960 & 0 & 68841.02 & 41.36688 & 0 & 7 \\
\hline $\mathrm{HCO}_{3}^{-}$ & -236.246 & 0 & 80160.2 & 9.67583 & 0 & 55 \\
\hline $\mathrm{SO}_{4}^{2-}$ & -300.285 & 0 & 96620.31 & 42.66527 & 0 & 7 \\
\hline $\operatorname{Si}(1,1)$ & -505.064 & 0 & 161966.7 & 0 & 0 & 38 \\
\hline $\operatorname{Si}(2,1)$ & -458.242 & 0 & 131188 & 0 & 0 & 38 \\
\hline $\operatorname{Si}(2,2)$ & -450.841 & 0 & 141043.4 & 0 & 0 & 38 \\
\hline $\operatorname{Si}(4,2)$ & -421.193 & 0 & 120657.6 & 0 & 0 & 38 \\
\hline $\operatorname{Si}(6,3)$ & -382.663 & 0 & 131398.4 & 0 & 0 & 38 \\
\hline $\operatorname{Si}(2,4)$ & -417.759 & 0 & 135166.3 & 0 & 0 & 38 \\
\hline $\operatorname{Si}(4,4)$ & -407.813 & 0 & 126749.7 & 0 & 0 & 38 \\
\hline $\operatorname{Si}(6,6)$ & -359.192 & 0 & 109394.7 & 0 & 0 & 38 \\
\hline $\operatorname{Si}(4,8)$ & -357.764 & 0 & 110000 & 0 & 0 & 38 \\
\hline $\operatorname{Si}(8,8)$ & -357.379 & 0 & 107550.4 & 0 & 0 & 38 \\
\hline $\mathrm{C}_{2} \mathrm{O}_{4}^{2-}$ & -271.956 & 0 & 81933.21 & 57.9329 & 0 & 7 \\
\hline $\operatorname{Si}(0,1)$ & -527.652 & 0 & 180643.6 & -16.778 & 0 & 7 \\
\hline $\mathrm{Al}(\mathrm{OH})_{3}$ & -465.971 & 0 & 155087.8 & 1.583907 & 0 & 7 \\
\hline $\mathrm{NaNO}_{3}$ & -147.822 & 0 & 61480.8 & -19.1222 & 0 & \\
\hline $\mathrm{NaNO}_{2}$ & -114.658 & 0 & 42970.1 & 0 & 0 & \\
\hline $\mathrm{Na}_{2} \mathrm{CO}_{3} \cdot \mathrm{H}_{2} \mathrm{O}$ & -518.372 & 0 & 168431.7 & 0 & 0 & 38 \\
\hline $\mathrm{Na}_{2} \mathrm{CO}_{3} \cdot 7 \mathrm{H}_{2} \mathrm{O}$ & -1094.799 & 0 & 387532.6 & 0 & 0 & 38 \\
\hline $\mathrm{Na}_{2} \mathrm{CO}_{3} \cdot 10 \mathrm{H}_{2} \mathrm{O}$ & -1382.743 & 0 & 493460.2 & 0 & 0 & 38 \\
\hline $\mathrm{KNO}_{3}$ & -158.891 & 0 & 0 & 0 & 0 & \\
\hline $\mathrm{NaCl}$ & -155.030 & 1.198614 & 0 & 0 & -0.0012 & \\
\hline $\mathrm{KCl}$ & -164.878 & 0 & 0 & 0 & 0 & \\
\hline
\end{tabular}


Table A.1 (continued)

\begin{tabular}{crrrrrr}
\hline & \multicolumn{1}{c}{$\mathrm{A}$} & \multicolumn{1}{c}{$\mathrm{B}$} & $\mathrm{C}$ & $\mathrm{D}$ & $\mathrm{E}$ & Ref. \\
\hline $\mathrm{NaF}$ & -219.391 & 2.022907 & 0 & 0 & -0.00209 & 51 \\
$\mathrm{Na}_{3} \mathrm{PO}_{4} \cdot 12 \mathrm{H}_{2} \mathrm{O} \cdot{ }^{1}{ }_{4} \mathrm{NaOH}$ & -1926.923 & -1351 & $-4.2 \mathrm{E}+07$ & 415570.9 & 0.731171 & 50 \\
$\mathrm{Na}_{2} \mathrm{HPO}_{4} \cdot 12 \mathrm{H}_{2} \mathrm{O}$ & -1803.470 & 7.65392 & 0 & 0 & 0 & 50 \\
$2 \mathrm{Na}_{3} \mathrm{PO}_{4} \cdot \mathrm{NaF} \cdot 19 \mathrm{H}_{2} \mathrm{O}$ & -3512.445 & 36.15256 & 0 & 0 & -0.03774 & 51 \\
$\mathrm{UO}_{2}(\mathrm{OH})_{2}$ & 532.673 & 5.422982 & 0 & 0 & -0.00561 & 52 \\
$\mathrm{Na}_{2} \mathrm{U}_{2} \mathrm{O}_{7}$ & -1113.060 & 11.34351 & 0 & 0 & -0.01175 & 53 \\
$\mathrm{SiO}_{2}(\mathrm{am})$ & -342.486 & 0 & 112091.7 & -11.4904 & 0 & 38 \\
$\mathrm{OH}_{-}$sodalite & -5350.580 & & 1547994 & -191.791 & & 38 \\
$\mathrm{NO}_{3}-\mathrm{cancrinite}_{\mathrm{K}}$ & -5454.573 & 0 & 1465869 & 0 & 0 & 38 \\
$\mathrm{~K}_{2} \mathrm{C}_{2} \mathrm{O}_{4} \cdot \mathrm{W}$ & -596.677 & 0 & 172341.5 & 82.73543 & 0 & \\
$\mathrm{Na}_{2} \mathrm{C}_{2} \mathrm{O}_{4}$ & -488.595 & 0 & 157821.3 & 21.23335 & 0 & \\
$\mathrm{Na}_{2} \mathrm{SO}_{4}$ & -513.057 & 4.78648 & 0 & 0 & -0.0049 & 54 \\
$\mathrm{Na}_{2} \mathrm{SO}_{4} \cdot 10 \mathrm{H}_{2} \mathrm{O}$ & -1472.023 & 15.5281 & 0 & 0 & -0.01624 & 54 \\
$\mathrm{Na}_{2} \mathrm{SO}_{4} \cdot \mathrm{NaNO}_{3} \cdot 2 \mathrm{H}_{2} \mathrm{O}$ & -852.691 & 8.84139 & 0 & 0 & -0.00932 & 54 \\
\hline
\end{tabular}

${ }^{a}$ Omission of reference number indicates values were determined in the course of this study. 
Table A.2. Binary Pitzer Parameters

\begin{tabular}{|c|c|c|c|c|c|c|c|c|}
\hline \multicolumn{2}{|c|}{ Ionic species } & \multirow{2}{*}{$\frac{\text { Parameter }}{\beta^{(0)}}$} & \multirow{2}{*}{$\frac{\mathrm{A}}{0.00204}$} & \multirow{2}{*}{$\begin{array}{ll}\mathrm{B} & \\
& 0\end{array}$} & \multirow{2}{*}{$\begin{array}{l}\mathrm{C} \\
406.5\end{array}$} & \multirow{2}{*}{$\frac{\mathrm{D}}{-1.04}$} & \multirow{2}{*}{$\begin{array}{l}\text { Temp. } \\
0-100\end{array}$} & \multirow[t]{2}{*}{ Ref } \\
\hline $\mathrm{Na}^{+}$ & $\mathrm{NO}_{3}^{-}$ & & & & & & & \\
\hline $\mathrm{Na}^{+}$ & $\mathrm{NO}_{3}^{-}$ & $\beta^{(1)}$ & 0.2368 & 0 & 712.4 & -1.214 & & \\
\hline $\mathrm{Na}^{+}$ & $\mathrm{NO}_{3}^{-}$ & $\mathrm{C}$ & 0.00008 & 0 & -27.22 & 0.0756 & & \\
\hline $\mathrm{Na}^{+}$ & $\mathrm{OH}^{-}$ & $\beta^{(0)}$ & 0.0869 & 0 & 356.02 & -1.0814 & $0-150$ & 10 \\
\hline $\mathrm{Na}^{+}$ & $\mathrm{OH}^{-}$ & $\beta^{(1)}$ & 0.2481 & 0 & -173.16 & 1.2073 & & 10 \\
\hline $\mathrm{Na}^{+}$ & $\mathrm{OH}^{-}$ & $\mathrm{C}$ & 0.0039 & 0 & -34.22 & 0.0842 & & 10 \\
\hline $\mathrm{Na}^{+}$ & $\mathrm{Cl}^{-}$ & $\beta^{(0)}$ & 0.0743 & 0 & 283.52 & -0.7325 & $0-150$ & 10 \\
\hline $\mathrm{Na}^{+}$ & $\mathrm{Cl}^{-}$ & $\beta^{(1)}$ & 0.2744 & 0 & -15.68 & 0.3162 & & 10 \\
\hline $\mathrm{Na}^{+}$ & $\mathrm{Cl}^{-}$ & $\mathrm{C}$ & 0.0008 & 0 & -15.47 & 0.0354 & & 10 \\
\hline $\mathrm{Na}^{+}$ & $\mathrm{F}^{-}$ & $\beta^{(0)}$ & 0.033 & 0 & 246.8 & -0.6728 & $0-100$ & 51 \\
\hline $\mathrm{Na}^{+}$ & $\mathrm{F}^{-}$ & $\beta^{(1)}$ & 0.2456 & 0 & 2833 & -9.451 & & 51 \\
\hline $\mathrm{Na}^{+}$ & $\mathrm{F}^{-}$ & $\mathrm{C}$ & 0.00281 & 0 & 12.25 & -0.0436 & & 51 \\
\hline $\mathrm{Na}^{+}$ & $\mathrm{PO}_{4}^{3-}$ & $\beta^{(0)}$ & 0.2534 & 0 & 130.3 & 0.1247 & $0-100$ & 50 \\
\hline $\mathrm{Na}^{+}$ & $\mathrm{PO}_{4}^{3-}$ & $\beta^{(1)}$ & 3.7384 & 0 & 23420 & -70.37 & & 50 \\
\hline $\mathrm{Na}^{+}$ & $\mathrm{PO}_{4}^{3-}$ & $\mathrm{C}$ & -0.0226 & 0 & 0 & -0.00016 & & 50 \\
\hline $\mathrm{Na}^{+}$ & $\mathrm{HPO}_{4}^{2-}$ & $\beta^{(0)}$ & -0.03045 & 0 & 1826 & -5.159 & 0-100 & 50 \\
\hline $\mathrm{Na}^{+}$ & $\mathrm{HPO}_{4}^{2-}$ & $\beta^{(1)}$ & 1.3504 & 0 & 6023 & -18.77 & & 50 \\
\hline $\mathrm{Na}^{+}$ & $\mathrm{HPO}_{4}^{2-}$ & $\mathrm{C}$ & 0.00359 & 0 & -282.6 & 0.8267 & & 50 \\
\hline $\mathrm{Na}^{+}$ & $\mathrm{NO}_{2}^{-}$ & $\beta^{(0)}$ & 0.0498 & 0 & -165.6 & 0.5931 & $25-100$ & \\
\hline $\mathrm{Na}^{+}$ & $\mathrm{NO}_{2}^{-}$ & $\beta^{(1)}$ & 0.2177 & 0 & 3124 & -8.621 & & \\
\hline $\mathrm{Na}^{+}$ & $\mathrm{NO}_{2}^{-}$ & $\mathrm{C}$ & -0.0012 & 0 & 10.71 & -0.0364 & & \\
\hline $\mathrm{Na}^{+}$ & $\mathrm{Al}(\mathrm{OH})_{4}^{-}$ & $\beta^{(0)}$ & 0.0513 & 0 & 356.02 & -1.0814 & $0-100$ & 39 \\
\hline $\mathrm{Na}^{+}$ & $\mathrm{Al}(\mathrm{OH})_{4}^{-}$ & $\beta^{(1)}$ & 0.2481 & 0 & -173.16 & 1.2073 & & 39 \\
\hline $\mathrm{Na}^{+}$ & $\mathrm{Al}(\mathrm{OH})_{4}^{-}$ & $\mathrm{C}$ & 0.0013 & 0 & -34.22 & 0.0842 & & 39 \\
\hline $\mathrm{Na}^{+}$ & $\mathrm{CO}_{3}^{2-}$ & $\beta^{(0)}$ & 0.0362 & -0.0233 & -1108.38 & 11.19856 & $0-90$ & 55 \\
\hline $\mathrm{Na}^{+}$ & $\mathrm{CO}_{3}^{2-}$ & $\beta^{(1)}$ & 1.51 & -0.09989 & -4412.51 & 44.58207 & & 55 \\
\hline $\mathrm{Na}^{+}$ & $\mathrm{CO}_{3}^{2-}$ & $\mathrm{C}$ & 0.00184 & & & & & 55 \\
\hline $\mathrm{Na}^{+}$ & $\mathrm{HCO}_{3}^{-}$ & $\beta^{(0)}$ & 0.028 & -0.01446 & -682.886 & 6.899586 & $0-90$ & 55 \\
\hline $\mathrm{Na}+$ & $\mathrm{HCO}_{3}^{-}$ & $\beta^{(1)}$ & 0.044 & -0.02447 & -1129.39 & 11.41086 & & 55 \\
\hline $\mathrm{Na}^{+}$ & $\mathrm{SO}_{4}^{2-}$ & $\beta^{(0)}$ & 0.0262 & 0 & 570.6 & -1.3547 & $25-130$ & 54 \\
\hline $\mathrm{Na}^{+}$ & $\mathrm{SO}_{4}^{2-}$ & $\beta^{(1)}$ & 1.0277 & 0 & -85.69 & 2.017 & & 54 \\
\hline $\mathrm{Na}^{+}$ & $\mathrm{SO}_{4}^{2-}$ & $\mathrm{C}$ & 0.00126 & 0 & -35.37 & 0.0811 & & 54 \\
\hline $\mathrm{Na}^{+}$ & $\mathrm{C}_{2} \mathrm{O}_{4}^{2-}$ & $\beta^{(0)}$ & 0.1621 & 0 & -1452 & & $0-110$ & \\
\hline $\mathrm{Na}^{+}$ & $\mathrm{C}_{2} \mathrm{O}_{4}^{2-}$ & $\beta^{(1)}$ & 1.4533 & 0 & 16676 & & & \\
\hline
\end{tabular}


Table A.2 (continued)

\begin{tabular}{|c|c|c|c|c|c|c|c|c|}
\hline \multicolumn{2}{|c|}{ Ionic Strength } & \multirow{2}{*}{$\frac{\text { Parameter }}{\mathrm{C}}$} & \multirow{2}{*}{$\frac{\mathrm{A}}{-0.0822}$} & \multirow{2}{*}{ B } & \multirow{2}{*}{$\begin{array}{l}\mathrm{C} \\
142\end{array}$} & \multirow[t]{2}{*}{$\mathrm{D}$} & \multirow[t]{2}{*}{ Temp. } & \multirow[t]{2}{*}{ Ref. } \\
\hline $\mathrm{Na}^{+}$ & $\mathrm{C}_{2} \mathrm{O}_{4}^{2-}$ & & & & & & & \\
\hline $\mathrm{Na}^{+}$ & $\operatorname{Si}(1,1)$ & $\beta^{(0)}$ & -2.2564 & & -1838 & & $20-102$ & 38 \\
\hline $\mathrm{Na}^{+}$ & $\operatorname{Si}(1,1)$ & $\beta^{(1)}$ & 10.7265 & & & & & 38 \\
\hline $\mathrm{Na}^{+}$ & $\operatorname{Si}(1,1)$ & $\mathrm{C}$ & 0.2744 & & & & & 38 \\
\hline $\mathrm{Na}^{+}$ & $\operatorname{Si}(2,1)$ & $\beta^{(0)}$ & 0.9477 & & 67.23 & & $20-102$ & 38 \\
\hline $\mathrm{Na}^{+}$ & $\operatorname{Si}(2,1)$ & $\beta^{(1)}$ & -27.1254 & & & & & 38 \\
\hline $\mathrm{Na}^{+}$ & $\operatorname{Si}(2,1)$ & $\mathrm{C}$ & -0.0915 & & & & & 38 \\
\hline $\mathrm{Na}^{+}$ & $\operatorname{Si}(2,2)$ & $\beta^{(0)}$ & -0.1343 & & -1092 & & $20-102$ & 38 \\
\hline $\mathrm{Na}^{+}$ & $\operatorname{Si}(2,2)$ & $\beta^{(1)}$ & -7.6464 & & & & & 38 \\
\hline $\mathrm{Na}^{+}$ & $\operatorname{Si}(2,2)$ & $\mathrm{C}$ & -0.0043 & & & & & 38 \\
\hline $\mathrm{Na}^{+}$ & $\operatorname{Si}(4,2)$ & $\beta^{(0)}$ & 0.2362 & & -265.1 & & $20-102$ & 38 \\
\hline $\mathrm{Na}^{+}$ & $\operatorname{Si}(4,2)$ & $\beta^{(1)}$ & -11.6927 & & & & & 38 \\
\hline $\mathrm{Na}^{+}$ & $\operatorname{Si}(4,2)$ & $\mathrm{C}$ & -0.0136 & & & & & 38 \\
\hline $\mathrm{Na}^{+}$ & $\operatorname{Si}(6,3)$ & $\beta^{(0)}$ & 0.3825 & & -2029 & & $20-102$ & 38 \\
\hline $\mathrm{Na}^{+}$ & $\operatorname{Si}(6,3)$ & $\beta^{(1)}$ & 1.1225 & & & & & 38 \\
\hline $\mathrm{Na}^{+}$ & $\operatorname{Si}(6,3)$ & $\mathrm{C}$ & -0.0293 & & & & & 38 \\
\hline $\mathrm{Na}^{+}$ & $\operatorname{Si}(2,4)$ & $\beta^{(0)}$ & -0.4831 & & -1159 & & $20-102$ & 38 \\
\hline $\mathrm{Na}^{+}$ & $\operatorname{Si}(2,4)$ & $\beta^{(1)}$ & -3.82 & & & & & 38 \\
\hline $\mathrm{Na}^{+}$ & $\operatorname{Si}(2,4)$ & $\mathrm{C}$ & 0.0218 & & & & & 38 \\
\hline $\mathrm{Na}^{+}$ & $\operatorname{Si}(4,4)$ & $\beta^{(0)}$ & -0.347 & & -1548 & & $20-102$ & 38 \\
\hline $\mathrm{Na}^{+}$ & $\operatorname{Si}(4,4)$ & $\beta^{(1)}$ & -1.6082 & & & & & 38 \\
\hline $\mathrm{Na}^{+}$ & $\operatorname{Si}(4,4)$ & $\mathrm{C}$ & 0.0083 & & & & & 38 \\
\hline $\mathrm{Na}^{+}$ & $\operatorname{Si}(6,6)$ & $\beta^{(0)}$ & -0.4626 & & -1580 & & $20-102$ & 38 \\
\hline $\mathrm{Na}^{+}$ & $\operatorname{Si}(6,6)$ & $\beta^{(1)}$ & -0.9638 & & & & & 38 \\
\hline $\mathrm{Na}^{+}$ & $\operatorname{Si}(6,6)$ & $\mathrm{C}$ & 0.0167 & & & & & 38 \\
\hline $\mathrm{Na}^{+}$ & $\operatorname{Si}(4,8)$ & $\beta^{(0)}$ & -2.7046 & & 0 & & $20-102$ & 38 \\
\hline $\mathrm{Na}^{+}$ & $\operatorname{Si}(4,8)$ & $\beta^{(1)}$ & 6.2351 & & & & & 38 \\
\hline $\mathrm{Na}^{+}$ & $\operatorname{Si}(4,8)$ & $\mathrm{C}$ & 0.1148 & & & & & 38 \\
\hline $\mathrm{Na}^{+}$ & $\operatorname{Si}(8,8)$ & $\beta^{(0)}$ & 0.0031 & & -121.9 & & $20-102$ & 38 \\
\hline $\mathrm{Na}^{+}$ & $\operatorname{Si}(8,8)$ & $\beta^{(1)}$ & -8.3161 & & & & & 38 \\
\hline $\mathrm{Na}^{+}$ & $\operatorname{Si}(8,8)$ & $\mathrm{C}$ & -0.0089 & & & & & 38 \\
\hline $\mathrm{K}^{+}$ & $\mathrm{NO}_{3}^{-}$ & $\beta^{(0)}$ & -0.0806 & 0 & 428.7 & -0.9718 & $0-100$ & \\
\hline $\mathrm{K}^{+}$ & $\mathrm{NO}_{3}^{-}$ & $\beta^{(1)}$ & 0.0764 & 0 & 1362 & -2.698 & & \\
\hline $\mathrm{K}^{+}$ & $\mathrm{NO}_{3}^{-}$ & $\mathrm{C}$ & 0.0025 & 0 & -24.3 & 0.0619 & & \\
\hline $\mathrm{K}^{+}$ & $\mathrm{OH}^{-}$ & $\beta^{(0)}$ & 0.1632 & 0 & -567.6 & 1.77 & $0-100$ & \\
\hline $\mathrm{K}^{+}$ & $\mathrm{OH}^{-}$ & $\beta^{(1)}$ & 0.097 & 0 & 9256 & -29.83 & & \\
\hline $\mathrm{K}^{+}$ & $\mathrm{OH}^{-}$ & $\mathrm{C}$ & -0.0007 & 0 & 25.54 & -0.0864 & & \\
\hline $\mathrm{K}^{+}$ & $\mathrm{Cl}^{-}$ & $\beta^{(0)}$ & 0.0475 & 0 & 191.98 & -0.4764 & $0-150$ & 10 \\
\hline $\mathrm{K}^{+}$ & $\mathrm{Cl}^{-}$ & $\beta^{(1)}$ & 0.2148 & 0 & 46.73 & 0.2695 & & 10 \\
\hline $\mathrm{K}^{+}$ & $\mathrm{Cl}^{-}$ & $\mathrm{C}$ & -0.0003 & 0 & 137.72 & -0.6513 & & 10 \\
\hline $\mathrm{K}^{+}$ & $\mathrm{F}^{-}$ & $\beta^{(0)}$ & 0.08089 & & & & & 10 \\
\hline $\mathrm{K}^{+}$ & $\mathrm{F}^{-}$ & $\beta^{(1)}$ & 0.2021 & & & & & 10 \\
\hline
\end{tabular}


Table A.2 (continued)

\begin{tabular}{|c|c|c|c|c|c|c|c|c|}
\hline \multicolumn{2}{|c|}{ Ionic Strength } & \multirow{2}{*}{$\frac{\text { Parameter }}{\mathrm{C}}$} & \multirow{2}{*}{$\frac{\mathrm{A}}{0.00046}$} & \multirow[t]{2}{*}{$\mathrm{B}$} & \multirow[t]{2}{*}{$\mathrm{C}$} & \multirow[t]{2}{*}{$\mathrm{D}$} & \multirow[t]{2}{*}{ Temp. } & \multirow{2}{*}{$\frac{\text { Ref. }}{10}$} \\
\hline $\mathrm{K}^{+}$ & $\mathrm{F}^{-}$ & & & & & & & \\
\hline $\mathrm{K}^{+}$ & $\mathrm{PO}_{4}^{3-}$ & $\beta^{(0)}$ & 0.2585 & & & & & 10 \\
\hline $\mathrm{K}^{+}$ & $\mathrm{PO}_{4}^{3-}$ & $\beta^{(1)}$ & 4.316 & & & & & 10 \\
\hline $\mathrm{K}^{+}$ & $\mathrm{PO}_{4}^{3-}$ & $\mathrm{C}$ & -0.00029 & & & & & 10 \\
\hline $\mathrm{K}^{+}$ & $\mathrm{HPO}_{4}^{2-}$ & $\beta^{(0)}$ & 0.0248 & & & & & 10 \\
\hline $\mathrm{K}^{+}$ & $\mathrm{HPO}_{4}^{2-}$ & $\beta^{(1)}$ & 1.2743 & & & & & 10 \\
\hline $\mathrm{K}+$ & $\mathrm{HPO}_{4}^{2-}$ & $\mathrm{C}$ & 0.0058 & & & & & 10 \\
\hline $\mathrm{K}^{+}$ & $\mathrm{NO}_{2}^{-}$ & $\beta^{(0)}$ & 0.0128 & 0 & -339.2 & -0.8802 & $0-100$ & \\
\hline $\mathrm{K}^{+}$ & $\mathrm{NO}_{2}^{-}$ & $\beta^{(1)}$ & 0.0668 & 0 & 37818 & -113.6 & & \\
\hline $\mathrm{K}^{+}$ & $\mathrm{NO}_{2}^{-}$ & $\mathrm{C}$ & -0.0005 & 0 & -6.567 & 0.01522 & & \\
\hline $\mathrm{K}^{+}$ & $\mathrm{Al}(\mathrm{OH})_{4}^{-}$ & $\beta^{(0)}$ & 0.1276 & 0 & -567.6 & 1.77 & $0-100$ & 39 \\
\hline $\mathrm{K}^{+}$ & $\mathrm{Al}(\mathrm{OH})_{4}^{-}$ & $\beta^{(1)}$ & 0.097 & 0 & 9256 & -29.83 & & 39 \\
\hline $\mathrm{K}^{+}$ & $\mathrm{Al}(\mathrm{OH})_{4}^{-}$ & $\mathrm{C}$ & -0.006 & 0 & 25.54 & -0.0864 & & 39 \\
\hline $\mathrm{K}^{+}$ & $\mathrm{CO}_{3}^{2-}$ & $\beta^{(0)}$ & 0.1288 & 0.0011 & $-1.81 \mathrm{E}-05$ & 0 & 0-90 & 55 \\
\hline $\mathrm{K}^{+}$ & $\mathrm{CO}_{3}^{2-}$ & $\beta^{(1)}$ & 1.433 & 0.00436 & -0.00119 & 0 & & 55 \\
\hline $\mathrm{K}^{+}$ & $\mathrm{CO}_{3}^{2-}$ & $\mathrm{C}$ & -0.00018 & 0 & 0 & 0 & & 55 \\
\hline $\mathrm{K}^{+}$ & $\mathrm{HCO}_{3}^{-}$ & $\beta^{(0)}$ & -0.01071 & 0.001 & 0.000699 & $-4.70 \mathrm{E}-06$ & $0-90$ & 55 \\
\hline $\mathrm{K}^{+}$ & $\mathrm{HCO}_{3}^{-}$ & $\beta^{(1)}$ & 0.0478 & 0.0011 & -0.00094 & $6.16 \mathrm{E}-06$ & & 55 \\
\hline $\mathrm{K}^{+}$ & $\mathrm{C}_{2} \mathrm{O}_{4}^{2-}$ & $\beta^{(0)}$ & 0.0643 & & 85.52 & & $0-108$ & \\
\hline $\mathrm{K}^{+}$ & $\mathrm{C}_{2} \mathrm{O}_{4}^{2-}$ & $\beta^{(1)}$ & 1.5235 & & 650.2 & & & \\
\hline $\mathrm{K}^{+}$ & $\mathrm{C}_{2} \mathrm{O}_{4}^{2-}$ & $\mathrm{C}$ & 0.0005 & & -3.712 & & & \\
\hline $\mathrm{H}^{+}$ & $\mathrm{NO}_{3}^{-}$ & $\beta^{(0)}$ & 0.1168 & & & & & 10 \\
\hline $\mathrm{H}^{+}$ & $\mathrm{NO}_{3}^{-}$ & $\beta^{(1)}$ & 0.3546 & & & & & 10 \\
\hline $\mathrm{H}^{+}$ & $\mathrm{NO}_{3}^{-}$ & $\mathrm{C}$ & -0.0027 & & & & & 10 \\
\hline $\mathrm{H}^{+}$ & $\mathrm{Cl}^{-}$ & $\beta^{(0)}$ & 0.1769 & & & & & 10 \\
\hline $\mathrm{H}^{+}$ & $\mathrm{Cl}^{-}$ & $\beta^{(1)}$ & 0.2973 & & & & & 10 \\
\hline $\mathrm{H}^{+}$ & $\mathrm{Cl}^{-}$ & $\mathrm{C}$ & 0.000362 & & & & & 10 \\
\hline $\mathrm{UO}_{2}^{2+}$ & $\mathrm{NO}_{3}^{-}$ & $\beta^{(0)}$ & 0.4607 & & & & & 10 \\
\hline $\mathrm{UO}_{2}^{2+}$ & $\mathrm{NO}_{3}^{-}$ & $\beta^{(1)}$ & 1.6133 & & & & & 10 \\
\hline $\mathrm{UO}_{2}^{2+}$ & $\mathrm{NO}_{3}^{-}$ & $\mathrm{C}$ & -0.01115 & & & & & 10 \\
\hline $\mathrm{UO}_{2}^{2+}$ & $\mathrm{OH}^{-}$ & $\beta^{(0)}$ & 0.4274 & & & & & 10 \\
\hline
\end{tabular}


Table A.2 (continued)

\begin{tabular}{|c|c|c|c|c|c|c|c|c|}
\hline \multicolumn{2}{|c|}{ Ionic Strength } & \multirow{2}{*}{$\frac{\text { Parameter }}{\beta^{(1)}}$} & \multirow{2}{*}{$\frac{\mathrm{A}}{1.644}$} & \multirow[t]{2}{*}{$\mathrm{B}$} & \multirow[t]{2}{*}{$\mathrm{C}$} & \multirow[t]{2}{*}{$\mathrm{D}$} & \multirow[t]{2}{*}{ Temp. } & \multirow{2}{*}{$\frac{\text { Ref }}{10}$} \\
\hline $\mathrm{UO}_{2}^{2+}$ & $\mathrm{OH}^{-}$ & & & & & & & \\
\hline $\mathrm{UO}_{2}^{2+}$ & $\mathrm{OH}^{-}$ & $\mathrm{C}$ & -0.01303 & & & & & 10 \\
\hline $\mathrm{UO}_{2}^{2+}$ & $\mathrm{Cl}^{-}$ & $\beta^{(0)}$ & 0.4607 & & & & & 10 \\
\hline $\mathrm{UO}_{2}^{2+}$ & $\mathrm{Cl}^{-}$ & $\beta^{(1)}$ & 1.6133 & & & & & 10 \\
\hline $\mathrm{UO}_{2}^{2+}$ & $\mathrm{Cl}^{-}$ & $\mathrm{C}$ & -0.01115 & & & & & 10 \\
\hline $\mathrm{UO}_{2}^{2+}$ & $\mathrm{CO}_{3}^{2-}$ & $\beta^{(0)}$ & 0.4607 & & & & & 10 \\
\hline $\mathrm{UO}_{2}^{2+}$ & $\mathrm{CO}_{3}^{2-}$ & $\beta^{(1)}$ & 1.6133 & & & & & 10 \\
\hline $\mathrm{UO}_{2}^{2+}$ & $\mathrm{CO}_{3}^{2-}$ & $\mathrm{C}$ & -0.01115 & & & & & 10 \\
\hline $\mathrm{UO}_{2}^{2+}$ & $\mathrm{HCO}_{3}^{-}$ & $\beta^{(0)}$ & 0.322 & & & & & 10 \\
\hline $\mathrm{UO}_{2}^{2+}$ & $\mathrm{HCO}_{3}^{-}$ & $\beta^{(1)}$ & 1.827 & & & & & 10 \\
\hline $\mathrm{UO}_{2}^{2+}$ & $\mathrm{HCO}_{3}^{-}$ & $\mathrm{C}$ & -0.0176 & & & & & 10 \\
\hline
\end{tabular}


Table A.3. Ternary Pitzer Parameters

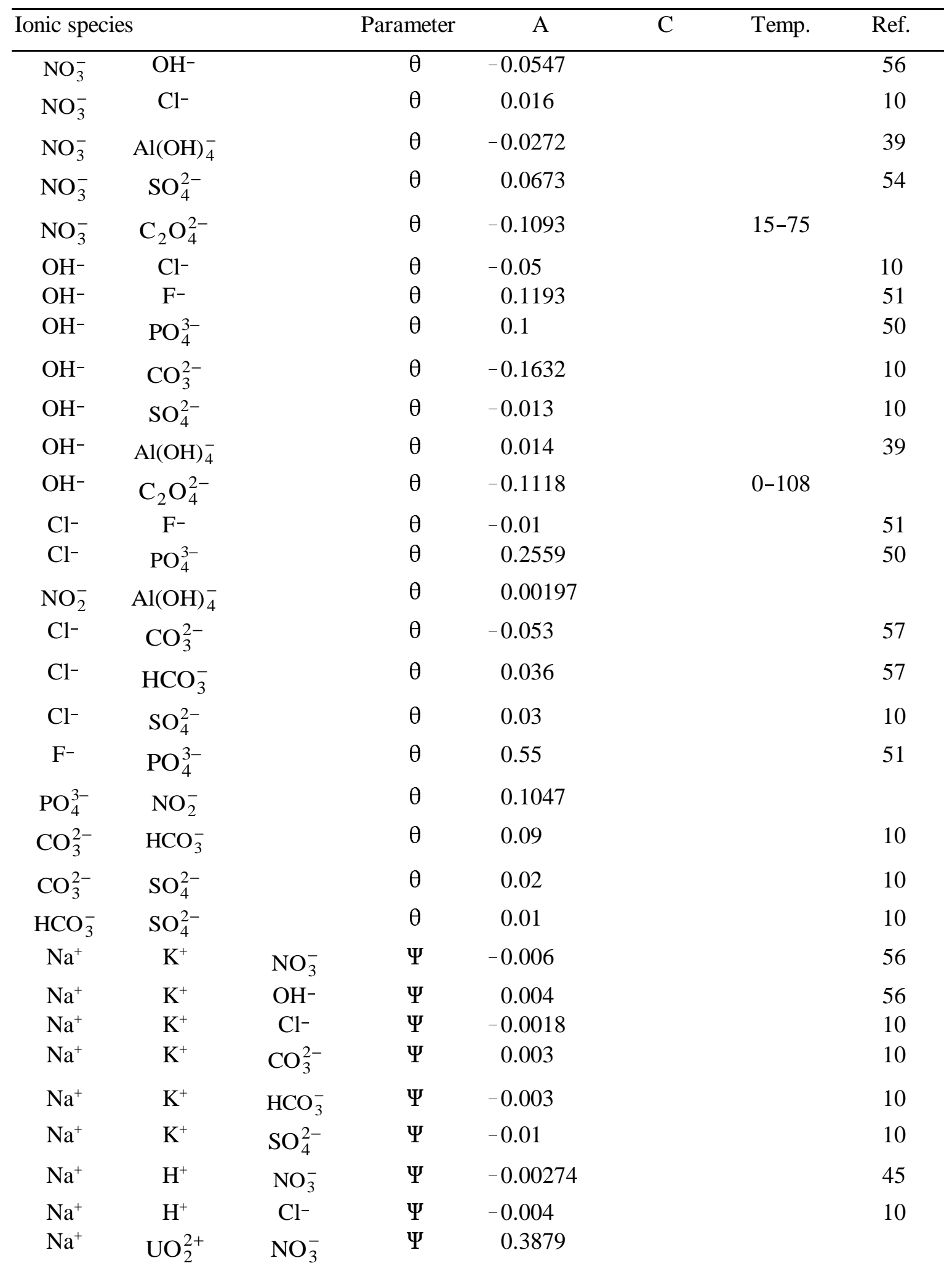


Table A.3 (continued)

\begin{tabular}{|c|c|c|c|c|c|c|c|}
\hline \multicolumn{3}{|c|}{ Ionic Species } & \multirow{2}{*}{$\frac{\text { Parameter }}{\Psi}$} & \multirow{2}{*}{$\frac{\mathrm{A}}{-0.2556}$} & \multirow[t]{2}{*}{$\mathrm{C}$} & \multirow[t]{2}{*}{ Temp. } & \multirow[t]{2}{*}{ Ref } \\
\hline $\mathrm{Na}^{+}$ & $\mathrm{UO}_{2}^{2+}$ & $\mathrm{OH}^{-}$ & & & & & \\
\hline $\mathrm{Na}^{+}$ & $\mathrm{NO}_{3}^{-}$ & $\mathrm{OH}^{-}$ & $\Psi$ & 0.0002 & & & 56 \\
\hline $\mathrm{Na}^{+}$ & $\mathrm{NO}_{3}^{-}$ & $\mathrm{Cl}^{-}$ & $\Psi$ & -0.006 & & & 56 \\
\hline $\mathrm{Na}^{+}$ & $\mathrm{NO}_{3}^{-}$ & $\mathrm{Al}(\mathrm{OH})_{4}^{-}$ & $\Psi$ & 0.0047 & & & 39 \\
\hline $\mathrm{Na}^{+}$ & $\mathrm{NO}_{3}^{-}$ & $\mathrm{SO}_{4}^{2-}$ & $\Psi$ & 0.00335 & & & 54 \\
\hline $\mathrm{Na}^{+}$ & $\mathrm{NO}_{3}^{-}$ & $\mathrm{C}_{2} \mathrm{O}_{4}^{2-}$ & $\Psi$ & 0.1895 & -95.66 & $15-75$ & \\
\hline $\mathrm{Na}^{+}$ & $\mathrm{OH}^{-}$ & $\mathrm{Cl}^{-}$ & $\Psi$ & -0.0063 & & & 10 \\
\hline $\mathrm{Na}^{+}$ & $\mathrm{OH}^{-}$ & $\mathrm{F}^{-}$ & $\Psi$ & -0.035 & & & 51 \\
\hline $\mathrm{Na}^{+}$ & $\mathrm{OH}^{-}$ & $\mathrm{PO}_{4}^{3-}$ & $\Psi$ & 0.03 & & & 50 \\
\hline $\mathrm{Na}^{+}$ & $\mathrm{OH}^{-}$ & $\mathrm{CO}_{3}^{2-}$ & $\Psi$ & 0.0172 & & & 10 \\
\hline $\mathrm{Na}^{+}$ & $\mathrm{OH}^{-}$ & $\mathrm{SO}_{4}^{2-}$ & $\Psi$ & -0.009 & & & 10 \\
\hline $\mathrm{Na}^{+}$ & $\mathrm{OH}^{-}$ & $\mathrm{Al}(\mathrm{OH})_{4}^{-}$ & $\Psi$ & -0.0048 & & & 39 \\
\hline $\mathrm{Na}^{+}$ & $\mathrm{OH}^{-}$ & $\mathrm{C}_{2} \mathrm{O}_{4}^{2-}$ & $\Psi$ & 0.1 & & $0-108$ & \\
\hline $\mathrm{Na}^{+}$ & $\mathrm{Cl}^{-}$ & $\mathrm{F}^{-}$ & $\Psi$ & -0.00218 & & & 51 \\
\hline $\mathrm{Na}^{+}$ & $\mathrm{Cl}^{-}$ & $\mathrm{PO}_{4}^{3-}$ & $\Psi$ & 0 & & & 50 \\
\hline $\mathrm{Na}^{+}$ & $\mathrm{Cl}^{-}$ & $\mathrm{CO}_{3}^{2-}$ & $\Psi$ & 0.0085 & & & 10 \\
\hline $\mathrm{Na}^{+}$ & $\mathrm{Cl}^{-}$ & $\mathrm{HCO}_{3}^{-}$ & $\Psi$ & -0.015 & & & 10 \\
\hline $\mathrm{Na}^{+}$ & $\mathrm{Cl}^{-}$ & $\mathrm{SO}_{4}^{2-}$ & $\Psi$ & 0 & & & 10 \\
\hline $\mathrm{Na}^{+}$ & $\mathrm{F}^{-}$ & $\mathrm{PO}_{4}^{3-}$ & $\Psi$ & 0 & & & 51 \\
\hline $\mathrm{Na}^{+}$ & $\mathrm{F}^{-}$ & $\mathrm{HPO}_{4}^{2}$ & $\Psi$ & 0 & & & 51 \\
\hline $\mathrm{Na}^{+}$ & $\mathrm{PO}_{4}^{3-}$ & $\mathrm{NO}_{2}^{-}$ & $\Psi$ & 0.0537 & & & \\
\hline $\mathrm{Na}^{+}$ & $\mathrm{CO}_{3}^{2-}$ & $\mathrm{HCO}_{3}^{-}$ & $\Psi$ & 0.002 & & & 10 \\
\hline $\mathrm{Na}^{+}$ & $\mathrm{CO}_{3}^{2-}$ & $\mathrm{SO}_{4}^{2-}$ & $\Psi$ & -0.005 & & & 10 \\
\hline $\mathrm{Na}^{+}$ & $\mathrm{HCO}_{3}^{-}$ & $\mathrm{SO}_{4}^{2-}$ & $\Psi$ & -0.005 & & & 10 \\
\hline $\mathrm{Na}^{+}$ & $\mathrm{NO}_{2}^{-}$ & $\mathrm{Al}(\mathrm{OH})_{4}^{-}$ & $\Psi$ & 0.0054 & & & \\
\hline $\mathrm{Na}^{+}$ & $\mathrm{NO}_{2}^{-}$ & $\mathrm{C}_{2} \mathrm{O}_{4}^{2-}$ & $\Psi$ & 0.23 & & & \\
\hline $\mathrm{K}^{+}$ & $\mathrm{H}+$ & $\mathrm{NO}_{3}^{-}$ & $\Psi$ & -0.0103 & & & 56 \\
\hline $\mathrm{K}^{+}$ & $\mathrm{H}^{+}$ & $\mathrm{Cl}^{-}$ & $\Psi$ & -0.011 & & & 56 \\
\hline $\mathrm{K}^{+}$ & $\mathrm{NO}_{3}^{-}$ & $\mathrm{OH}^{-}$ & $\Psi$ & -0.0032 & & & 56 \\
\hline $\mathrm{K}^{+}$ & $\mathrm{NO}_{3}^{-}$ & $\mathrm{Cl}^{-}$ & $\Psi$ & -0.0031 & & & 56 \\
\hline $\mathrm{K}^{+}$ & $\mathrm{OH}^{-}$ & $\mathrm{Cl}^{-}$ & $\Psi$ & -0.0032 & & & 56 \\
\hline $\mathrm{K}^{+}$ & $\mathrm{OH}^{-}$ & $\mathrm{CO}_{3}^{2-}$ & $\Psi$ & -0.01 & & & 10 \\
\hline
\end{tabular}


Table A.3 (continued)

\begin{tabular}{|c|c|c|c|c|c|c|c|}
\hline Ionic Species & & & Parameter & $\mathrm{A}$ & $\mathrm{C}$ & Temp. & Ref. \\
\hline $\mathrm{K}^{+}$ & $\mathrm{OH}^{-}$ & $\mathrm{SO}_{4}^{2-}$ & $\Psi$ & -0.05 & & & 10 \\
\hline $\mathrm{K}^{+}$ & $\mathrm{OH}^{-}$ & $\mathrm{C}_{2} \mathrm{O}_{4}^{2-}$ & $\Psi$ & 0.005 & & $0-108$ & \\
\hline $\mathrm{K}^{+}$ & $\mathrm{Cl}^{-}$ & $\mathrm{F}^{-}$ & $\Psi$ & -0.0135 & & & 51 \\
\hline $\mathrm{K}^{+}$ & $\mathrm{Cl}^{-}$ & $\mathrm{CO}_{3}^{2-}$ & $\Psi$ & 0.004 & & & 10 \\
\hline $\mathrm{K}^{+}$ & $\mathrm{Cl}^{-}$ & $\mathrm{HCO}_{3}^{-}$ & $\Psi$ & -0.015 & & & 10 \\
\hline $\mathrm{K}^{+}$ & $\mathrm{Cl}^{-}$ & $\mathrm{SO}_{4}^{2-}$ & $\Psi$ & -0.005 & & & 10 \\
\hline $\mathrm{K}^{+}$ & $\mathrm{CO}_{3}^{2-}$ & $\mathrm{SO}_{4}^{2-}$ & $\Psi$ & -0.009 & & & 10 \\
\hline $\mathrm{K}^{+}$ & $\mathrm{HCO}_{3}^{-}$ & $\mathrm{SO}_{4}^{2-}$ & $\Psi$ & 0.005 & & & 10 \\
\hline $\mathrm{Na}^{+}$ & $\operatorname{Si}(0,1)$ & & $\lambda$ & 0 & & & 38 \\
\hline $\mathrm{NO}_{3}^{-}$ & $\operatorname{Si}(0,1)$ & & $\lambda$ & 0.0563 & & & 38 \\
\hline $\mathrm{Cl}^{-}$ & $\operatorname{Si}(0,1)$ & & $\lambda$ & 0.0478 & & & 38 \\
\hline $\mathrm{K}^{+}$ & $\operatorname{Si}(0,1)$ & & $\lambda$ & -0.0504 & & & 38 \\
\hline
\end{tabular}




\section{INTERNAL DISTRIBUTION}

1. W. C. Carter, 6011, MS-6370

2. D. W. Depaoli, 4501, MS-6223

3. M. B. Emmett, 6011 , MS-6370

4. R. D. Hunt, 4500 N, MS-6223

5. R. T. Jubin, 4501, MS-6223

6. T. E. Kent, 4501, MS-6223

7. M. A. Kuliasha, 6025 , MS-6435

8. A. J. Mattus, 4501, MS-6221
9. C. P. McGinnis, 4500 N, MS-6176

10. C. V. Parks, 6011, MS-6370

11. P. A. Taylor, 4501, MS-6221

12-15. C. F. Weber, 6011, MS-6370

16. ORNL Laboratory Records 4500N, MS-6254

17. Central Research Library 4500N, MS-6191

\section{EXTERNAL DISTRIBUTION}

18. J. T. Carter, Westinghouse Savannah River Company, P.O. Box 616, Bldg. 704-3N, Room S151, Aiken, SC 29808

19. C. F. Jove Colon, Sandia National Laboratory, P.O. Box 5800 / MS 0750, Albuquerque, NM 87185-0750

20. S. D. Fink, Westinghouse Savannah River Co., P.O. Box 616, Bldg. 773-A, Room B112, Aiken, SC 29808

21. F. F. Fondeur, Westinghouse Savannah River Co., P.O. Box 616, Bldg.773A, Aiken, SC 29808

22. M. W. Geeting, Westinghouse Savannah River Co., P.O. Box 616, Bldg.704-196N, Room S411, Aiken, SC 29808

23. H. D. Harmon, Tank Focus Area Salt Processing Program, P.O. Box 616, Bldg. 704-3N, Room S151, Aiken, SC 29808

24. D. T. Hobbs, Westinghouse Savannah River Co., P.O. Box 616, Bldg.773A, Aiken, SC 29808

25. R. A. Jacobs, Westinghouse Savannah River Co., P.O. Box 616, Bldg. 704-3N, Room S252, Aiken, SC 29808

26. C. M. Jantzen, Westinghouse Savannah River Co., P.O. Box 616, Bldg.773A, Aiken, SC 29808

27. J. L. Krumhansl, Sandia National Laboratory, P.O. Box 5800 / MS 0750, Albuquerque, NM 87185-0750

28. J. E. Laurinat, Westinghouse Savannah River Co., P.O. Box 616, Bldg.773A, Aiken, SC 29808 
29-30. Office of Scientific and Technical Information, U.S. Department of Energy, P.O. Box 62, Oak Ridge, TN 37831

31. J. A. Pike, Westinghouse Savannah River Co., P.O. Box 616, 704-3N, Room S151, Aiken, SC 29808

32. S. N. Schlahta, Tank Focus Area Salt Processing Program, P.O. Box 616, 704-3N, Room S151, Aiken, SC 29808

33. W. Tamosaitis, Westinghouse Savannah River Co., P.O. Box 616, Bldg.773A, Aiken, SC 29808

34. D. D. Walker, Westinghouse Savannah River Co., P.O. Box 616, Bldg.773A, Room G-124, Aiken, SC 29808

35. D. W. Wester, Pacific Northwest National Laboratory, P.O. Box 999 / MS P7-25, Richland, WA 99352

36. W. R. Wilmarth, Westinghouse Savannah River Co., P.O. Box 616, Bldg.773A, Aiken, SC 29808

37. Tanks Focus Area Technical Team, c/o B. J. Williams, Pacific Northwest National Laboratory, PO Box 999, MSIN K9-69, Richland, WA 99352

38. Tanks Focus Area Program Lead, c/o T. P. Pietrok, U.S. Department of Energy, Richland Operations Office, PO Box 550, MS: K8-50, Richland, WA 99352

39. Tanks Focus Area Headquarters Program Manager, c/o K. D. Gerdes, DOE Office of Science and Technology, 19901 Germantown Rd., 1154 Cloverleaf Bldg., Germantown, MD 20874-1290 